\title{
24. SATURATED BULK DENSITY, GRAIN DENSITY AND POROSITY OF SEDIMENT CORES FROM THE WESTERN EQUATORIAL PACIFIC: LEG 7, GLOMAR CHALLENGER
}

\author{
E. L. Gealy, Scripps Institution of Oceanography, University of California, La Jolla, California
}

\section{INTRODUCTION}

Knowledge of the saturated bulk density and porosity of marine sediments in situ is important to the understanding, not only of a variety of other physical properties (including compressibility, rigidity, strength, seismic characteristics, thermal conductivity, electrical properties, etc.), but is critical to the understanding of the dynamics of sediment consolidation and diagenesis.

Penetration of sequences of marine sediments to depths as great as one kilometer beneath the sea floor by a drilling program of the Deep Sea Drilling Project provides a unique opportunity for determining changes in saturated bulk density with depth and age for a variety of sediment types. The Glomar Challenger lacks a regular program whereby the saturated bulk density of sediments in situ is measured by means of proximal sensing devices lowered in the drilled hole. This lack is unfortunate because, neglecting errors in measurement, two problems make it difficult to estimate the in situ saturated bulk density of rocks and sediments by the laboratory measurements of cored materials:

First, rocks and sediments expand on being brought from in situ pressure and temperatures to surface conditions. A study of cores from the caribbian by Gealy and Gerard (1970), showed that the effects of thermal expansion on marine sediments recovered are smaller than errors in measurement, and can be ignored. However, the study showed that the effect of the release of the sediments from in situ confining pressure on the volume and porosity of the sediments recovered may be substantial. When values of porosity measured on cores from Site 29 (Leg IV at the Glomar Challenger were compared with values derived from in situ neutron logging, it was found that porosity of the cores was consistently higher than the in situ equivalent and the differences increase 0.81 whereas values of porosity in situ were only 0.61 .

Second, the drilling and core recovery process may pack, sort, dilute or otherwise contaminate cores so that measurements of saturated bulk density or porosity of retrieved samples may differ markedly from in situ properties. These disturbances are discussed in detail earlier in this volume.

Three techniques for measuring or deriving wet bulk density and/or porosity are available aboard the Glomar Challenger: 1) by dividing the net weight of each core section in its liner by the volume of the liner; 2 ) by scanning the cored section with gamma rays and measuring the attenuation; and 3 ) by measuring the weight of small samples of known volume before and after drying. Because the validity of the results obtained by these techniques was in question, additional samples of larger volume were taken from the cores on shore, and measurements of saturated bulk density, grain density and porosity were made under conditions more controlled than can be obtained at sea. This report presents, compares and evaluates the results of these several techniques.

\section{DEFINITIONS AND PROPERTY RELATIONSHIPS}

Terms used in this report are defined:

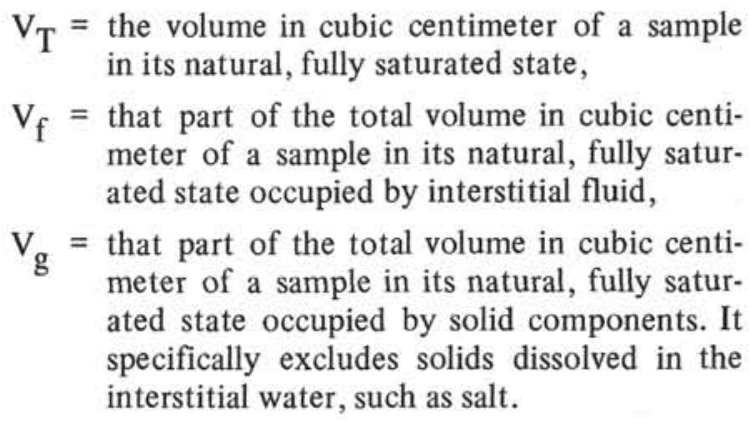

thus: $\quad \mathrm{V}_{\mathrm{T}}=\mathrm{V}_{\mathrm{f}}+\mathrm{V}_{\mathrm{g}}$
$\mathrm{W}_{\mathrm{T}}=$ the weight in grams of the sample in its nat- ural, fully saturated state,
$\mathrm{W}_{\mathrm{f}}=$ that part of the total weight in grams of a sample in its natural, fully saturated state attributable to the interstitial fluid,
$\mathrm{W}_{\mathrm{g}}=$ that part of the total weight in grams of a sample in its natural, fully saturated state attributable to its solid components. It spe- cifically excludes solids dissolved in the inter- stitial water.

thus: $\quad \mathrm{W}_{\mathrm{T}}=\mathrm{W}_{\mathrm{f}}+\mathrm{w}_{\mathrm{g}}$

When a sample saturated in brine is dried at $105^{\circ}$ to $110^{\circ} \mathrm{C}$, the evaporated water is driven off, but the salt remains in the dried mineral residue.

\footnotetext{
$\mathrm{W}_{\mathrm{w}}=$ weight in grams of the water evaporated from a sediment sample in its natural, fully saturated state, by oven drying at $110^{\circ} \pm 05^{\circ} \mathrm{C}$.
} 
$\mathrm{W}_{\mathrm{S}}=$ dry weight in grams of the salt dissolved in the interstitial fluid in a sample in its natural, fully saturated state.

thus:

$$
\mathrm{w}_{\mathrm{f}}=\mathrm{w}_{\mathrm{w}}+\mathrm{w}_{\mathrm{s}}
$$

and: the dry weight of the sample is $\mathrm{W}_{\mathrm{g}}+\mathrm{W}_{\mathrm{S}}$

$\phi=$ porosity is that fraction of the total volume of a sample in its natural, fully saturated state not occupied by solid components,

$\rho_{\mathrm{W}}=$ density of evaporated water at a specified temperature,

$\rho_{\mathrm{g}}=$ mean bulk density in grams per cubic centimeter of the solid component of a sample, excluding solids dissolved in the interstitial water.

or: $\quad \rho_{\mathrm{g}}=\frac{\mathrm{W}_{\mathrm{g}}}{\mathrm{V}_{\mathrm{g}}}$ in grams per cubic centimeter

$\rho_{\mathrm{f}}=$ density in grams per cubic centimeter of the interstitial fluid in a sediment sample at its natural salinity.

or: $\quad \rho_{\mathrm{f}}=\frac{\mathrm{W}_{\mathrm{f}}}{\mathrm{V}_{\mathrm{f}}}$ in grams per cubic centimeter

$\rho_{\mathrm{B}}=$ saturated bulk density in grams per cubic centimeter of a natural, fully saturated sediment sample.

or: $\quad \rho_{\mathrm{B}}=\frac{\mathrm{W}_{\mathrm{T}}}{\mathrm{V}_{\mathrm{T}}}$ in grams per cubic centimeter

and: $\quad \rho_{\mathrm{B}}=\phi \rho_{\mathrm{f}}+(1-\phi) \rho_{\mathrm{g}}$

Any one of $\phi, \rho_{\mathrm{B}}$ or $\rho_{\mathrm{g}}$ can be derived, provided that the values of the other two are known.

Measurements of salinity of a number of interstitial water samples squeezed from sediments cored in Leg 7 indicate that the salinity of the interstitial water deviates only slightly from 35 per mille. In this report, the density of the interstitial water is assumed to be 1.024 $\mathrm{gm} / \mathrm{cm}^{3}$, the density of sea water at 35 per mille at $23^{\circ} \mathrm{C}$ (U.S. Navy Hydrographic Office, Publication 615).

\footnotetext{
$\phi^{\prime}=$ apparent porosity is that fraction of the total volume of a sample in its natural, fully saturated state occupied by water evaporated by
}

oven drying at $105^{\circ} \pm 05^{\circ} \mathrm{C}$; it assumes that one gram evaporated water $=1 \mathrm{~cm}^{3}$ water:

$$
\phi=\frac{\mathrm{W}_{\mathrm{w}}}{\mathrm{V}_{\mathrm{T}}}=\frac{\mathrm{W}_{\mathrm{T}}-\left(\mathrm{W}_{\mathrm{g}}+\mathrm{W}_{\mathrm{s}}\right)}{\mathrm{V}_{\mathrm{T}}}
$$

Several methods exist for correcting apparent porosity for the salt remaining in the dry sample. For purposes of this report, an empirical multiplier from Hamilton (1969) is used:

$$
\phi=\phi^{\prime} \times 1.012
$$

\section{TECHNIQUES}

\section{Saturated Bulk Density from Net Core Section Weight}

Upon removal from the steel core barrel, the core in its plastic liner is cut immediately into sections 150 centimeters in length, and the sections are capped and taped. They are stored at room temperature for periods of several hours to several days awaiting processing. Each unopened section is then weighed to the nearest 10 grams, a constant value for the tare weight of the empty core liner and plastic caps is subtracted, and the saturated bulk density is calculated by dividing the remainder by the volume of a liner 150 centimeters in length.

The method presumes that both the tare weight and the volume of the section are constant. Examination of a number of core section liners indicates that their length is likely to be greater than 150 centimeters, rather than less, and lengths in the range of 151 to 154 centimeters are common. At 154 centimeters, a core having a saturated bulk density of $2.00 \mathrm{gm} / \mathrm{cm}^{3}$ would yield an apparent value of $2.053 \mathrm{gm} / \mathrm{cm}^{3}$. Except where recovery is incomplete, liners are commonly full and, in a number of cases, split cores rise above the liner edge by a millimeter or two, indicating expansion. Errors in saturated bulk density derived from section weight due to variations in tare weight and section volume should be less than $\pm .05 \mathrm{gm} / \mathrm{cm}^{3}$ and, for data presented in this report, are more likely to be positive than negative.

A greater source of error evolves from the fact that liners are often not completely filled with sediment or are filled in part with drilling fluid or a slurry of drilled materials and sea water. Where it is obvious that these conditions would yield misleading measurements, the sections are not weighed.

Values of saturated bulk density obtained by this technique are shown in the tables at the end of Chapters 3 through 9. Selected values are repeated for comparison purposes in Table 1 of this chapter. 
TABLE 1

Saturated Bulk Density, Grain Density and Porosity of Sediment Samples from the Western Equatorial Pacific

\begin{tabular}{|c|c|c|c|c|c|c|c|c|c|c|c|c|c|c|c|c|}
\hline & \multirow[b]{2}{*}{$\begin{array}{l}\text { Interval } \\
\text { From Top } \\
\text { (cm) }\end{array}$} & \multirow[b]{2}{*}{ Lithology } & \multirow{2}{*}{$\begin{array}{c}\text { Section Wt. } \\
\text { Saturated } \\
\text { Bulk } \\
\text { Density } \\
\left(\mathrm{gm} / \mathrm{cm}^{3}\right) \\
\end{array}$} & \multirow{2}{*}{$\begin{array}{c}\text { GRAPE } \\
\text { Saturated } \\
\text { Bulk } \\
\text { Density } \\
\left(\mathrm{gm} / \mathrm{cm}^{3}\right) \\
\end{array}$} & \multicolumn{3}{|c|}{ Tube Method } & \multicolumn{3}{|c|}{ Pycnometer Method } & \multicolumn{3}{|c|}{ Jolly Balance Method } & \multicolumn{3}{|c|}{ Grain Density $\rho_{\mathrm{G}}\left(\mathrm{gm} / \mathrm{cm}^{3}\right)$} \\
\hline & & & & & \begin{tabular}{c|} 
Saturated \\
Bulk \\
Density \\
$\left(\mathrm{gm} / \mathrm{cm}^{3}\right)$
\end{tabular} & $\begin{array}{l}\text { Uncorrected } \\
\text { Porosity } \%\end{array}$ & $\begin{array}{l}\text { Porosity, } \\
\text { Corrected } \\
\text { For Salt \% }\end{array}$ & \begin{tabular}{|l|} 
Saturated \\
Bulk \\
Density \\
$\left(\mathrm{gm} / \mathrm{cm}^{3}\right)$ \\
\end{tabular} & $\begin{array}{l}\text { Uncorrected } \\
\text { Porosity \% }\end{array}$ & $\begin{array}{c}\text { Porosity, } \\
\text { Corrected } \\
\text { For Salt \% }\end{array}$ & $\begin{array}{l}\text { Specific } \\
\text { Gravity }\end{array}$ & $\begin{array}{l}\text { Uncorrected } \\
\text { Porosity \% }\end{array}$ & $\begin{array}{l}\text { Porosity, } \\
\text { Corrected } \\
\text { For Salt \% }\end{array}$ & $\begin{array}{l}\text { Derived From } \\
\rho \mathrm{B}+\phi=\left(\rho_{\mathrm{GD}}\right)\end{array}$ & $\begin{array}{c}\text { Measured } \\
\left(\rho_{\mathrm{GM}}\right)\end{array}$ & $\left.\rho_{\mathrm{GD}}-\rho_{\mathrm{GM}}\right)$ \\
\hline $61.1-1-2$ & $4.0-6.5$ & $\begin{array}{l}\text { Porcelanite, mud- } \\
\text { stone, (chert frag- } \\
\text { ments) }\end{array}$ & - & 1.84 & 1.60 & 63.6 & 64.4 & - & - & - & - & - & - & 2.65 & 2.64 & +0.01 \\
\hline $61.1-1-2$ & $135.5-137.0$ & $\begin{array}{l}\text { Porcelanite, mud- } \\
\text { stone (chert frag- } \\
\text { ments) }\end{array}$ & - & 1.84 & 1.56 & 64.4 & 65.2 & - & - & - & - & - & - & 2.70 & 2.64 & +0.06 \\
\hline $62.0-1-2$ & $50.0-60.5$ & $\begin{array}{l}\text { Nannofossil chalk } \\
\text { ooze }\end{array}$ & 1.42 & 1.67 & 1.64 & 62.7 & 63.5 & - & - & - & - & - & - & 2.71 & 2.71 & 0.00 \\
\hline $62,0-2-2$ & $90.0-92.5$ & $\begin{array}{l}\text { Nannofossil chalk } \\
\text { ooze }\end{array}$ & - & 1.73 & 1.75 & 55.8 & 56.5 & - & - & - & - & - & - & 2.69 & 2.71 & -0.02 \\
\hline $62.0-3-1$ & $27.5-30.0$ & $\begin{array}{l}\text { Nannofossil chalk } \\
\text { ooze }\end{array}$ & 1.77 & 1.75 & 1.62 & 58.5 & 59.2 & - & - & - & - & - & - & 2.52 & 2.71 & -0.19 \\
\hline $62.0-4-2$ & $139-141$ & $\begin{array}{l}\text { Nannofossil chalk } \\
\text { ooze and chalk } \\
\text { (biscuit) }\end{array}$ & 1.92 & 1.88 & - & - & - & 1.82 & 53.3 & 53.9 & 1.82 & 53.3 & 53.9 & 2.72 & 2.65 & +0.07 \\
\hline $62.0-4-2$ & $142.0-144.5$ & $\begin{array}{l}\text { Nannofossil chalk } \\
\text { ooze and chalk } \\
\text { (paste) }\end{array}$ & 1.92 & 1.88 & 1.71 & 55.5 & 56.2 & - & - & - & - & - & - & 2.67 & 2.68 & -0.01 \\
\hline $62.0-5-3$ & $91.0-93.5$ & $\begin{array}{l}\text { Nannofossil chalk } \\
\text { ooze and chalk }\end{array}$ & 1.89 & 1.90 & 1.83 & 51.9 & 52.5 & - & - & - & - & - & - & 2.72 & 2.69 & +0.03 \\
\hline $62.0-6-\mathrm{CC}$ & - & $\begin{array}{l}\text { Nannofc ssil chalk } \\
\text { limestone with } \\
\text { chert }\end{array}$ & - & - & - & - & - & 1.91 & 48.9 & 49.5 & 1.90 & 48.7 & 49.3 & 2.75 & 2.69 & +0.06 \\
\hline $62.0-7-1$ & $50-54$ & Dolomite (chunk) & - & - & - & - & - & 2.35 & 27.4 & 27.7 & 2.36 & 27.5 & 27.8 & 2.86 & - & - \\
\hline $63.0-1-2$ & $17.0-19.5$ & Pelagic clay & 1.34 & 1.41 & 1.31 & 79.8 & 80.8 & - & - & - & - & - & - & 2.78 & 2.72 & +0.06 \\
\hline $63.0-2-2$ & $122.5-125.0$ & $\begin{array}{l}\text { Nannofossil chalk } \\
\text { ooze }\end{array}$ & 1.61 & 1.63 & 1.50 & 68.8 & 69.6 & - & - & - & - & - & - & 2.73 & 2.70 & +0.03 \\
\hline 63.0-4-1 & $50.5-53.0$ & $\begin{array}{l}\text { Nannofossil chalk } \\
\text { ooze (paste) }\end{array}$ & - & 1.80 & 1.76 & 54.1 & 54.7 & - & - & - & - & - & - & 2.65 & 2.68 & -0.03 \\
\hline 63.0-4-1 & $118.5-121.0$ & $\begin{array}{l}\text { Nannofossil chalk } \\
\text { ooze (biscuit) }\end{array}$ & - & 1.80 & - & - & - & 1.78 & 55.9 & 56.6 & 1.78 & 55.9 & 56.6 & 2.77 & 2.73 & +0.04 \\
\hline $63.0-5-1$ & $17.5-19.5$ & $\begin{array}{l}\text { Nannofossil chalk } \\
\text { (biscuit) }\end{array}$ & - & 1.81 & - & - & - & 1.82 & 53.0 & 53.6 & 1.83 & 53.3 & 53.9 & 2.74 & 2.73 & +0.01 \\
\hline $63.0-5-1$ & $89.0-91.5$ & $\begin{array}{l}\text { Nannofossil chalk } \\
\text { (paste) }\end{array}$ & - & 1.81 & 1.89 & 45.9 & 46.5 & - & - & - & - & - & - & 2.72 & 2.73 & -0.01 \\
\hline $63.0-6-1$ & $64.0-67.5$ & Nannofossil chalk & 1.95 & 1.94 & - & - & - & 1.92 & 47.8 & 48.4 & 1.93 & 48.0 & 48.6 & 2.76 & 2.71 & +0.05 \\
\hline $63.0-6-1$ & $67.5-68.5$ & Nannofossil chalk & 1.95 & 1.94 & - & - & - & 2.08 & 39.0 & 39.5 & 2.09 & 39.1 & 39.6 & 2.77 & 2.73 & +0.04 \\
\hline $63.0-7-1$ & $12.5-14.0$ & $\begin{array}{l}\text { Nannofossil chalk } \\
\text { (biscuit) }\end{array}$ & 1.99 & 1.97 & - & - & - & 1.92 & 47.3 & 47.9 & 1.92 & 47.4 & 48.0 & 2.75 & 2.72 & +0.03 \\
\hline $63.0-7-1$ & $52.5-55.0$ & $\begin{array}{l}\text { Nannofossil chalk } \\
\text { (paste) }\end{array}$ & 1.99 & 1.97 & 1.94 & 42.5 & 43.0 & - & - & - & - & - & - & 2.73 & 2.71 & +0.02 \\
\hline $63.0-8-1$ & $140.0-141.5$ & $\begin{array}{l}\text { Nannofossil chalk } \\
\text { (biscuit) }\end{array}$ & - & 1.96 & - & - & - & 1.90 & 48.0 & 48.6 & 1.91 & 48.1 & 48.7 & 2.73 & 2.73 & 0.00 \\
\hline $63.0-9-1$ & $12.0-14.5$ & $\begin{array}{l}\text { Nannofossil chalk } \\
\text { (biscuit) }\end{array}$ & - & 2.08 & - & - & - & 2.04 & 40.7 & 41,2 & 2.05 & 40.9 & 41.4 & 2.75 & - & - \\
\hline $63.0-9-1$ & $48.0-50.5$ & $\begin{array}{l}\text { Nannofossil chalk } \\
\text { (paste) }\end{array}$ & - & 2.08 & 1.99 & 40.1 & 40.6 & - & - & - & - & - & - & 2.74 & 2.73 & +0.01 \\
\hline 63.1-5-1 & $19.5-22.0$ & $\begin{array}{l}\text { Nannofossil chalk } \\
\text { ooze }\end{array}$ & - & 1.55 & 1.51 & 68.1 & 68.9 & - & - & - & - & - & - & 2.59 & 2.68 & -0.09 \\
\hline
\end{tabular}


TABLE 1 - Continued

\begin{tabular}{|c|c|c|c|c|c|c|c|c|c|c|c|c|c|c|c|c|}
\hline & \multirow[b]{2}{*}{$\begin{array}{l}\text { Interval } \\
\text { From Top } \\
\text { (cm) }\end{array}$} & \multirow[b]{2}{*}{ Lithology } & \multirow[b]{2}{*}{$\begin{array}{c}\text { Section Wt. } \\
\text { Saturated } \\
\text { Bulk } \\
\text { Density } \\
\left(\mathrm{gm} / \mathrm{cm}^{3}\right)\end{array}$} & \multirow[b]{2}{*}{$\begin{array}{c}\text { GRAPE } \\
\text { Saturated } \\
\text { Bulk } \\
\text { Density } \\
\left(\mathrm{gm} / \mathrm{cm}^{3}\right)\end{array}$} & \multicolumn{3}{|c|}{ Tube Method } & \multicolumn{3}{|c|}{ Pycnometer Method } & \multicolumn{3}{|c|}{ Jolly Balance Method } & \multicolumn{3}{|c|}{ Grain Density $\rho_{\mathrm{G}}\left(\mathrm{gm} / \mathrm{cm}^{3}\right)$} \\
\hline & & & & & \begin{tabular}{c|} 
Saturated \\
Bulk \\
Density \\
$\left(\mathrm{gm} / \mathrm{cm}^{3}\right)$ \\
\end{tabular} & $\begin{array}{l}\text { Uncorrected } \\
\text { Porosity \% }\end{array}$ & $\begin{array}{l}\text { Porosity, } \\
\text { Corrected } \\
\text { For Salt \% }\end{array}$ & $\begin{array}{c}\text { Saturated } \\
\text { Bulk } \\
\text { Density } \\
\left(\mathrm{gm} / \mathrm{cm}^{3}\right) \\
\end{array}$ & $\begin{array}{l}\text { Uncorrected } \\
\text { Porosity \% }\end{array}$ & $\begin{array}{l}\text { Porosity, } \\
\text { Corrected } \\
\text { For Salt \% }\end{array}$ & $\begin{array}{l}\text { Specific } \\
\text { Gravity }\end{array}$ & $\begin{array}{l}\text { Uncorrected } \\
\text { Porosity \% }\end{array}$ & \begin{tabular}{|c|} 
Porosity, \\
Corrected \\
For Salt $\%$ \\
\end{tabular} & $\begin{array}{l}\text { Derived From } \\
\rho \mathrm{B}+\phi=\left(\rho_{\mathrm{GD}}\right)\end{array}$ & $\begin{array}{c}\text { Measured } \\
\left(\rho_{\mathrm{GM}}\right)\end{array}$ & $\rho_{\mathrm{GD}}+\rho_{\mathrm{GM}}$ \\
\hline 63.1-9-1 & 131.5-134.0 & $\begin{array}{l}\text { Nannofossil chalk } \\
\text { (paste) }\end{array}$ & 1.64 & 1.62 & 1.60 & 60.6 & 61.3 & - & - & - & - & - & - & 2.69 & 2.69 & 0.00 \\
\hline $63.1-14-1$ & $139.0-141.5$ & $\begin{array}{l}\text { Nannofossil chalk } \\
\text { (paste) }\end{array}$ & 1.65 & 1.69 & 1.70 & 56.7 & 57.4 & - & - & - & - & - & - & 2.72 & 2.69 & +0.03 \\
\hline 63.1-14-1 & $143.5-145.0$ & $\begin{array}{l}\text { Nannofossil chalk } \\
\text { (biscuit) }\end{array}$ & 1.65 & 1.69 & - & - & - & 1.67 & 62.9 & 63.7 & 1.67 & 62.9 & 63.7 & 2.80 & - & - \\
\hline $64.0-1-2$ & $60.5-63.0$ & $\begin{array}{l}\text { Foraminiferal, nan- } \\
\text { nofossil chalk ooze }\end{array}$ & - & 1.492 & 1.47 & 70.4 & 71.2 & - & - & - & - & - & - & 2.72 & 2.70 & +0.02 \\
\hline 64.0-3-3 & $144.5-147.0$ & $\begin{array}{l}\text { Nannofossil chalk } \\
\text { ooze }\end{array}$ & 1.65 & 1.72 & 1.62 & 60.9 & 61.6 & - & - & - & - & - & - & 2.70 & 2.72 & -0.02 \\
\hline $64.0-6-1$ & $2.0-4.5$ & $\begin{array}{l}\text { Nannofossil marl } \\
\text { ooze }\end{array}$ & - & 1.80 & 1.76 & 52.4 & 53.0 & - & - & - & - & - & - & 2.68 & 2.71 & -0.03 \\
\hline $64.0-6-5$ & $99.5-102.0$ & $\begin{array}{l}\text { Nannofossil chalk } \\
\text { ooze }\end{array}$ & 1.82 & 1.84 & 1.78 & 51.9 & 52.5 & - & - & - & - & - & - & 2.70 & 2.70 & 0.00 \\
\hline $64.0-6-6$ & $87.5-90.0$ & $\begin{array}{l}\text { Nannofossil chalk } \\
\text { ooze }\end{array}$ & 1.85 & 1.85 & 1.81 & 49.7 & 50.3 & - & - & - & - & - & - & 2.72 & 2.71 & +0.01 \\
\hline $64.0-6-\mathrm{CC}$ & - & $\begin{array}{l}\text { Nannofossil chalk } \\
\text { ooze (chunk) }\end{array}$ & - & - & - & - & - & 1.93 & 48.0 & 48.6 & 1.90 & 47.4 & 48.0 & 2.71 & 2.69 & +0.02 \\
\hline $64,0-10-2$ & $28.5-31.0$ & $\begin{array}{l}\text { Nannofossil chalk } \\
\text { (brittle \& porous) } \\
\text { and limestone }\end{array}$ & 1.92 & 1.95 & 1.83 & 48.9 & 49.5 & - & - & - & - & - & - & 2.68 & 2.70 & -0.02 \\
\hline $64.1-10-1$ & $56.5-59.0$ & $\begin{array}{l}\text { Nannofossil chalk } \\
\text { and limestone } \\
\text { (brittle \& porous) }\end{array}$ & - & 1.84 & 1.83 & 46.9 & 47.5 & - & - & - & - & - & - & 2.64 & 2.63 & +0.01 \\
\hline $64.1-10-\mathrm{CC}$ & - & $\begin{array}{l}\text { Nannofossil chalk } \\
\text { and limestone }\end{array}$ & - & - & - & - & - & - & - & - & $\begin{array}{l}\text { Poor } \\
2.05\end{array}$ & - & - & - & 2.68 & - \\
\hline $65.0-2-4$ & $119.0-121.5$ & Radiolarian ooze & - & 1.14 & 1.14 & 88.3 & 89.4 & - & - & - & - & - & - & 2.50 & 2.34 & +0.16 \\
\hline $65.0-6-2$ & $139.0-141.5$ & Radiolarian ooze & - & 1.15 & 1.16 & 85.3 & 86.3 & - & - & - & - & - & - & 2.29 & 2.28 & +0.01 \\
\hline $65.0-11-3$ & $32.0-34.5$ & Radiolarian ooze & - & 1.15 & 1.15 & 86.8 & 87.8 & - & - & - & - & - & - & 2.39 & 2.23 & +0.16 \\
\hline $65.0-14-3$ & $15.0-17.5$ & Radiolarian ooze & - & 1.20 & 1.20 & 82.7 & 83.7 & - & - & - & - & - & - & 2.10 & 2.16 & -0.06 \\
\hline $65.0-17-\mathrm{CC}$ & \#1 & & - & - & - & - & - & 2.13 & 15.4 & 15.6 & 2.13 & 15.4 & 15.6 & 2.33 & - & - \\
\hline & \#2 & & - & - & - & - & - & - & 14.4 & 14.6 & 2.14 & 14.4 & 14.6 & 2.33 & - & - \\
\hline & \#3 & & - & - & - & - & - & 2.12 & 16.3 & 16.5 & 2.13 & 17.0 & 17.2 & 2.34 & - & - \\
\hline & \#A & & - & - & - & - & - & 2.00 & 29.2 & 29.6 & 1.99 & 29.1 & 29.4 & 2.39 & - & - \\
\hline & \#B & & - & - & - & - & - & 1.84 & 39.0 & 39.5 & 1.86 & 39.4 & 39.9 & 2.38 & - & - \\
\hline $65.1-5.4$ & $110-112$ & Radiolarian ooze & - & 1.20 & 1.19 & 82.9 & 83.9 & - & - & - & - & - & - & 2.06 & 2.03 & +0.03 \\
\hline $65.1-5.4$ & $110-112$ & Chert & - & - & - & - & - & 2.03 & 18.8 & 19.0 & 2.03 & 19.3 & 19.5 & 2.33 & - & - \\
\hline $65.1-6-\mathrm{CC}$ & & Chert & - & - & - & - & - & 2.02 & 25.7 & 26.0 & 2.03 & 25.8 & 26.1 & 2.37 & - & - \\
\hline $66.0-3-1$ & $131.0-133.5$ & Radiolarian ooze & - & 1.16 & 1.14 & 86.9 & 87.9 & - & - & - & - & - & - & 2.33 & 2.21 & +0.12 \\
\hline $66.0-6-1$ & $83.0-85.5$ & Pelagic clay & - & 1.47 & 1.47 & 73.3 & 74.2 & - & - & - & - & - & - & 2.75 & 2.74 & +0.01 \\
\hline $66.0-7-1$ & $45-48$ & Pelagic clay & - & 1.56 & 1.49 & 73.2 & 74.1 & - & - & - & - & - & - & 2.82 & 2.77 & +0.05 \\
\hline $66.0-8-1$ & $31.0-33.5$ & Pelagic clay & - & 1.53 & 1.57 & 65.9 & 66.7 & - & - & - & - & - & - & 2.82 & 2.80 & +0.02 \\
\hline 66.0-9-1 & $114.0-116.5$ & Volcanic mud & - & 1.45 & 1.35 & 79.1 & 80.0 & - & - & - & - & - & - & 2.95 & 2.89 & +0.06 \\
\hline $66.1-2-1$ & & Radiolarian ooze & 1.14 & 1.18 & 1.13 & 90.1 & 91.2 & - & - & - & - & - & - & 2.70 & 2.58 & +0.12 \\
\hline $66.1-3-2$ & $58.5-61.0$ & Radiolarian ooze & - & 1.17 & 1.13 & 87.1 & 88.1 & - & - & - & - & - & - & 2.14 & 2.22 & -0.08 \\
\hline $66.1-4-1$ & Bottom 1/B & Radiolarian ooze & - & 1.19 & 1.14 & 88.7 & 88.8 & - & - & - & - & - & - & 2.41 & 2.30 & +0.11 \\
\hline $66.1-8-1$ & $12.5-15.0$ & Radiolarian ooze & - & 1.19 & 1.14 & 87.1 & 88.1 & - & - & - & - & - & - & 2.36 & 2.30 & +0.06 \\
\hline
\end{tabular}




\section{Gamma Ray Attenuation Porosity Evaluation}

The gamma ray attenuation porosity evaluation (GRAPE) technique depends on a system wherein a beam of parallel gamma rays of known intensity in the energy range 0.2 to about $4.0 \mathrm{MeV}$ are directed across the diameter of the unopened core section of known thickness. The system consists of a variable speed drive to move the core between the shielded gamma ray source and a shielded scintillation detector, an optical caliper to measure the thickness of the core in its liner, and an analog computer to calculate saturated bulk density and porosity from the measured parameters.

Some of the gamma rays penetrate the sediment without energy loss. Other incident gamma rays are absorbed or scattered out of the direct beam, resulting in an attenuation in the gamma rays received on the opposite side of the section. In the case of marine sediments, the number of source gamma rays which penetrate a given thickness of sediment depends almost entirely upon the electron density of the absorber, and the electron density is closely related to the saturated bulk density of the sample. Details of the theory and the instrumentation of the gamma ray attenuation technique are set forth in Volume II of the Initial Reports of the Deep Sea Drilling Project, 1970.

Unfortunately, digital output was not a part of the system on Leg 7. Calculated saturated bulk density, porosity and core diameter were traced on a strip recorder. The recorder was only marginally operative, and strip charts produced should be utilized with care. The strip recorder was geared to record measurements on a $1: 1$ scale, but the gear mechanism was faulty and delayed turning from time to time. Most of the charts obtained at Sites 61,62 and 63 record 150 centimeters of data on chart strips ranging in length from 130 to 140 centimeters in length. A uniform correction factor based on this ratio between the length of the core and the length of the chart is invalid because the gears slip sporadically, and the resulting error has not been demonstrated to be other than random. Recorder errors for cores scanned from Sites 64, 65, 66 and 67 are less than earlier ones.

Following procedures established prior to Leg 7, a set of four standards were run: sea water, karo syrup, drilling mud and aluminum, at the beginning of each core. The scientific party of Leg 7 used data only from the sea water and aluminum standard. The response of the system to these standards drifted considerably during the course of the cruise, although the responses to the standards between cores run consecutively were small. Although it was necessary to recalibrate the curves for each core, the likelihood that a calibration is valid for an entire core, if all sections are run at the same time, is high. In cases where all sections were not run at once, additional standards were run. In order to check the output, several sections were run twice. As might be expected, although major features coincide, minor features do not track, probably because rotation of the core presents a different sediment mass to the scanner.

On shore, 800 values per 150-centimeter section were digitized from the strip charts. By reference to the record of the salt water standard ( $\rho=1.03$ assumed) and of the aluminum standard ( $\rho=2.60$ assumed), a saturated bulk density was calculated for each of these values. Lacking a means of determining where in the section the gears had slipped, it was assumed that the slip was uniform. The curves presented on the core description and site summary charts in Chapters 3 through 9 of this report show data distributed uniformly along the section, provided that information indicated that the section was full. For the core description charts, successive pairs of values were averaged and plotted. For the site summary charts, successive groups of thirty values were averaged and plotted. A value of grain density was assigned to each core. The source of these values is discussed below, and they are listed in the tables of physical and chemical properties at the end of Chapters 3 through 9 .

The empirical determination of saturated bulk density from gamma ray attenuation measurements on cores depends on several assumptions. It assumes that the total attenuation of gamma rays by the sediment absorber (by photoelectric absorption, Compton scattering and pair production) is directly related to the saturated bulk density:

$$
\rho_{\mathrm{B}}=\frac{1}{\mu_{\mathrm{d}}} \ln \left[\mathrm{I}_{\mathrm{O}} / \mathrm{I}\right]
$$

where: $I_{0}=$ source intensity

$\mathrm{I}=$ intensity measured at detector

$\mu=$ mass absorption coefficient in square centimeters per gram

$\mathrm{d}=$ thickness of the absorber

It assumes that the density of the sea water standard is $1.024 \mathrm{gm} / \mathrm{cm}^{3}$, that the density of the aluminum standard is $2.60 \mathrm{gm} / \mathrm{cm}^{3}$, and that the relationship between $\rho_{\mathrm{B}}$ and $\mathrm{I}_{\mathrm{O}} / \mathrm{I}$ is linear. Thus, $\mu$ is assumed to be either a constant or to vary linearly with the saturated bulk density. In fact, $\mu$ is not a constant, but differs from one mineral component to another, although values of $\mu$ are similar for most common mineral constituents of marine sediments. The value of $\mu$ for brine is substantially different than that for common mineral constituents of marine sediments. However, because differences in the saturated bulk density of marine sediments are dominated by differences in brine 
content, the assumption that $\mu$ varies linearly with the saturated bulk density should result in negligible error.

A comparison of values of saturated bulk density by gamma ray attenuation and by other means shows that there is probably no systematic error in the measurement by gamma ray attenuation, which exceeds the random error of sampling and measurement.

A porosity value was calculated for each of the derived values of saturated bulk density, using the assigned value of grain density $\left(\rho_{\mathrm{g}}\right)$ and an assumed value of interstitial water density of 1.024. These porosities are displayed as a function of depth of the core description charts and site summary charts in Chapters 3 through 9.

Arithmetic averages of all values of saturated bulk density and of porosity in each section were determined, and these averages are given in the tables of physical and chemical properties at the end of Chapters 3 through 9. Selected values are repeated for comparison purposes in Table 1 of this chapter. The average values are exempt from the uncertain behavior of the strip recorder, and should be representative of the materials as a whole.

\section{Determination of Apparent Porosity Aboard Ship}

The apparent porosity of selected samples is measured aboard the Glomar Challenger in the following manner: An attempt is made to secure a 0.5 -cubic centimeter sediment sample in a plastic syringe. The 0.5-cubic centimeter sample is extruded onto a small aluminum tray, weighed, dried at $110^{\circ} \pm 5^{\circ} \mathrm{C}$, and weighed again. The tare weights are subtracted, and the water content $\left(\phi^{\prime}\right)$ is $\frac{\mathrm{W}_{\mathrm{W}}}{\mathrm{V}_{\mathrm{T}}}$.

When the cored material is relatively plastic, a sample of reasonably accurate volume can be secured, and the bulk densitites of samples otained in these intervals are comparable to values of saturated bulk density obtained by other means. However, in cores of consolidated (or indurated) materials, it is impossible to secure a sample of exactly 0.5 -cubic centimeter by the syringe technique. Also, in sequences of more and less consolidated materials, or in cases where drilling slurries have been mixed in with the cored materials, the syringe technique selectively removes the more plastic components. Considerable care was used in selecting the intervals to be sampled by this technique, and results achieved compare favorably with values derived by other methods. Values obtained are listed under Porosity (by drying) in the tables on physical and chemical properties at the end of Chapters 3 through 9. The values given are fractions of the sample volume occupied by brine at 35 per mille: $\phi=\phi^{\prime} X$ 1.012 .
In determining the weight of the water $\left(\mathrm{W}_{\mathrm{w}}\right)$, samples analyzed both on board ship and on shore were dried in ovens at $110^{\circ} \pm 5^{\circ} \mathrm{C}$. When clay minerals are important constitutents of sediments, the drying temperature is important in deriving porosity, water content, and grain density. In such sediments, there are three kinds of water: pore water, adsorbed water adjacent to mineral particles, and water of crystallization in the mineral structure. Increasing amounts of water are evaporated with increasing temperature. The drying temperature of $110^{\circ} \pm 5^{\circ} \mathrm{C}$ was selected because there is evidence that it evaporate pore water and adsorbed water, but not water of crystallization (ASTM, 1964). The effects of drying at lower and higher temperatures are illustrated by Igelman and Hamilton (1963). Thus, in fine-grained, clayey sediments any measured porosity, water content, or grain density is related to drying temperature, and the given value is true only at the given temperature. Also, selection of this drying temperature of $110^{\circ} \pm \mathrm{C}$ is in conformance with recommendations by the American Society for Testing Materials to standardize drying temperatures in all laboratories.

In addition to measurements made by the above technique, the saturated bulk density of selected samples of chert and silicified calcareous ooze was measured by weighing the saturated sample and observing the volume of water displaced by immersion in graduated beakers.

\section{Determination of Saturated Bulk Density, Grain Density and Porosity in Shore Based Laboratory}

In order to evaluate and supplement wet bulk density and porosity measurements made at sea on Leg 7, fifty-seven additional samples were taken from the core sections after they had been returned to Scripps Institution of Oceanography. Saturated bulk density, water content and grain density measurements were made under conditions more controlled than those possible aboard the Glomar Challenger.

The laboratory work was performed at the Naval Undersea Research and Development Center, San Diego by Richard Bachman (San Diego State College) and by Susan Oates (Scripps Institution of Oceanography). We are grateful to E. L. Hamilton of the Naval Undersea and Research Center in San Diego for permitting the use of his facilities, for advice concerning procedures, and for constructive criticism of results.

The techniques applied are modifications of methods in common use, and are described in many texts: the tube method of obtaining saturated bulk density and 
porosity is described in Hamilton (1956); the pycnometer method is described in Igelman and Hamilton (1963); and the Jolly balance method is described in Krumbein and Pettijohn (1938). The modifications of these techniques used in the present work are summarized below.

\section{Saturated Bulk Density: Tube Method}

Where sediments were plastic enough, they were sampled with specially prepared brass tubes, and the saturated bulk density and porosity were measured as follows:

The sampling equipment consists of brass cylinders made by cutting brass tubular stock of 7/8-inch diameters into lengths of $3 / 4$ inch, cutting one edge flat and smooth, and beveling the other for easy insertion. Each cylinder was numbered, weighed, and the volume of its sediment capacity determined.

In plastic sediments, the cylinder was inserted, sharp edge first, the cylinder with sample removed, excess material trimmed, and the ends capped with weighed plastic discs ( 2 by 1/8 inches), and held in place by rubber bands. The capped, sediment-filled cylinders were immersed in 35 per mille brine under a light vacuum for a time sufficient to allow resaturation. The sediment-filled tubes and caps were dried on the outside and placed on a watch glass and weighed rapidly to minimize the effect of sample drying. The caps were removed from the cylinders, and sediment adhering to the caps was washed into the watch glass with distilled water. Watch glass, cylinder and sediment units were dried for a minimum of 24 hours at $110^{\circ} \pm$ $5^{\circ} \mathrm{C}$, then cooled and held in a desiccator until they could be weighed.

From volume $\left(\mathrm{V}_{\mathrm{T}}\right)$, net weight of the saturated sample $\left(\mathrm{W}_{\mathrm{T}}\right)$ and the net weight of the dry sample $\left(\mathrm{W}_{\mathrm{g}}+\mathrm{W}_{\mathrm{s}}\right)$, saturated bulk density $\left(\rho_{\mathrm{B}}\right)$ and porosity $(\phi)$ were calculated:

$$
\begin{aligned}
\rho_{\mathrm{B}} & =\frac{\mathrm{W}_{\mathrm{T}}}{\mathrm{V}_{\mathrm{T}}} \\
\phi & =1.012 \frac{\mathrm{W}_{\mathrm{w}}}{\mathrm{V}_{\mathrm{T}}}
\end{aligned}
$$

\section{Saturated Bulk Density: Jolly Balance Method}

Samples of indurated materials were obtained by selecting or cutting a coherent piece of the core weighing about 10 grams. Samples were resaturated under 35 per mille brine under a light vacuum, and the specific gravity determined by standard Jolly balance techniques.
To measure the porosity of these samples, they were resaturated again under 35 per mille brine under a light vacuum, removed from the sea water, rinsed with distilled water, the outer surface dried and weighed. The sample was then dried in an oven at $105^{\circ}$ to $110^{\circ} \mathrm{C}$ for 24 hours or longer, as necessary to obtain a constant weight, cooled in a desiccator and weighed again. Calculation of porosity is the same as for the tube method.

\section{Grain Density and Saturated Bulk Density: Pycnometer Method}

The density of the mineral components $\left(\rho_{\mathrm{g}}\right)$ of the sediment samples and the saturated bulk density of some very small samples of indurated material was obtained by the pycnometer method.

Fifty-milliliter volumetric flasks were calibrated by being filled with distilled water placed in a constant temperature bath, adjusting the volume with a pipette, recording the temperature, and weighing the flask with contained water. A calibration curve was made of weight of the flask with water versus temperature using at least five temperatures in the range $10^{\circ}$ to $24^{\circ} \mathrm{C}$.

To measure grain density, the brine in the sample was removed by dispensing a 5 to 10 gram sample in distilled water, centrifuging, and decanting four times. The sample was transferred to a volumetric flask, and alternately evacuated and agitated to remove air bubbles. The flask was removed from the vacuum chamber, placed in a constant temperature bath, filled to the calibration mark with water, the temperature recorded, and the flask and its contents weighed $\left(\mathrm{W}_{\mathrm{T} 2}\right)$. The weight of the pycnometer filled with distilled water $\left(\mathrm{W}_{\mathrm{T} 1}\right)$ is read from the calibration curve above. The sample was transferred to a weighed 150 milliliter beaker, and dried for 24 hours at $110^{\circ} \pm 5^{\circ} \mathrm{C}$, which should drive off absorbed water, leaving molecular water intact. The samples were then cooled in a desiccator and weighed again. The dry weight less the tare weight equals $\mathrm{W}_{\mathrm{g}}$, the weight of the grains.

The weight of water displaced by the grains $=\left(\mathrm{W}_{\mathrm{w} 2}\right)=$ $\mathrm{W}_{\mathrm{T} 1}-\mathrm{W}_{\mathrm{T} 2}+\mathrm{w}_{\mathrm{g}}$.

The volume of the grains $\left(\mathrm{V}_{\mathrm{g}}\right)=\frac{\mathrm{W}_{\mathrm{w} 2}}{\rho_{\mathrm{w}}}$.

Where $\rho_{\mathrm{W}}=$ density distilled water at laboratory temperature, the grain density is then: $\rho_{\mathrm{g}}=\frac{\mathrm{W}_{\mathrm{g}}}{\mathrm{V}_{\mathrm{g}}}$.

The saturated bulk density of small indurated samples was obtained similarly. 
A comparison (Figure 2) of measurements of specific gravity by the Jolly balance method and of saturated bulk density by the pycnometer method indicates that there are no discernible differences between the two techniques.

\section{Errors in Determining Saturated Bulk Density, Porosity and Grain Density}

\section{Systematic Errors}

As mentioned above, removal of rocks and sediments from in situ conditions results in changes in porosity and saturated bulk density in particular, not only as a result of disturbance by the drilling and coring operation itself, but because the cores are removed from in situ pressure-temperature conditions. This removal may result in changes in porosity of some cored materials (especially radiolarian oozes) of as much as 20 per cent.

Another error derives from the fact that the density of the interstitial water is pressure and temperature dependent. Water having a salinity of 34.69 per mille will have a density $\rho_{\mathrm{f}}$ of $1.0237 \mathrm{gm} / \mathrm{cm}^{3}$ in the laboratory at $23^{\circ} \mathrm{C}$, and at 6000 meters below sea level, $\rho_{\mathrm{f}}=1.0550 \mathrm{gm} / \mathrm{cm}^{3}$ (Hamilton, 1969). For a sediment having a porosity of 0.80 and a grain density of $2.7 \mathrm{gm} / \mathrm{cm}^{3}$, the sediment will have a saturated bulk density of $1.359 \mathrm{gm} / \mathrm{cm}^{3}$ in the laboratory and 1.384 $\mathrm{gm} / \mathrm{cm}^{3}$ in situ, or an error of $0.025 \mathrm{gm} / \mathrm{cm}^{3}$.

\section{Procedural Errors}

Errors in laboratory measurement of saturated bulk density, grain density or porosity result from several factors:

Samples may be incompletely saturated. Air or gas trapped in or on a sample causes measured weights to be too low for the measured "saturated" sediment volume. Calculations of saturated bulk density and grain density will be too low, and porosity too high. Even submerging samples under a light vacuum does not remove all air or gas, and some remnant error from this source may be present in all cases.

Extraneous water or drilling fluid may fill cracks or holes in the samples sediments, rendering calculations of saturated bulk density too low and of porosity too high, although measured grain density should be accurate.

If the samples are insufficiently dried, the saturated bulk density will be correct, and the calculated porosity and grain density will be too low.

Measurements of the volume of the tubes can be erroneous. If the value used for volume is too high, saturated bulk density and calculated grain density will be too low, and porosity too high. Conversely, if the value of the volume is too low, the reverse errors will result.

\section{Errors in Measurement}

Assuming no procedural mistakes, weights of samples in the size range 5 to 25 grams, determined by weighing on an analytical balance, are accurate \pm 0.005 grams, and by weighing on Jolly balance, are accurate \pm 0.005 grams. Measurements of temperature are accurate to within $\pm 0.05^{\circ} \mathrm{C}$. The salt correction factor applied to water content measurements yields values of porosity accurate \pm 0.0005 . The temperature error results in an error of $\pm 0.000011 \mathrm{gm} / \mathrm{cm}^{3}$ in water density at $21^{\circ} \mathrm{C}$. Differences between the flask calibration data points and the computed calibration curve indicate that the pycnometer can be filled reproducibly within \pm 0.003 grams.

Applying the above uncertainties, errors in measurement were calculated for the following procedures on samples having saturated bulk densities in the range 1.2 to 2.0 :

$\begin{array}{ll}\begin{array}{l}\text { Saturated bulk density by tube } \\ \text { method }\end{array} & \pm 0.001 \mathrm{gm} / \mathrm{cm}^{3} \\ \begin{array}{l}\text { Porosity measured by tube } \\ \text { method }\end{array} & \pm 0.2 \% \\ \begin{array}{l}\text { Saturated bulk density by pyc- } \\ \text { nometer method }\end{array} & \pm 0.007 \mathrm{gm} / \mathrm{cm}^{3} \\ \begin{array}{l}\text { Porosity derived from pyc- } \\ \text { nometer method }\end{array} & \pm 0.3 \% \\ \begin{array}{l}\text { Specific gravity by Jolly balance } \\ \text { method }\end{array} & \pm 0.01 \mathrm{gm} / \mathrm{cm}^{3} \\ \begin{array}{l}\text { Porosity derived from Jolly } \\ \text { balance method }\end{array} & \pm 0.2 \% \\ \begin{array}{l}\text { Grain density by pycnometer } \\ \text { method }\end{array} & \pm 0.02 \mathrm{gm} / \mathrm{cm}^{3}\end{array}$

\section{Comparison of Measured and Derived Values of Grain Density}

Grain density can be derived, provided that the saturated bulk density, porosity, and the density of the interstitial fluid are known by:

$$
\rho_{\mathrm{g}}=\frac{\rho_{\mathrm{B}} \cdot \phi \rho_{\mathrm{F}}}{1-\phi}
$$

A graphic solution for all pairs of measurements of porosity and saturated bulk density is shown on Figure 1, and derived values of grain density are listed on Table 2. 


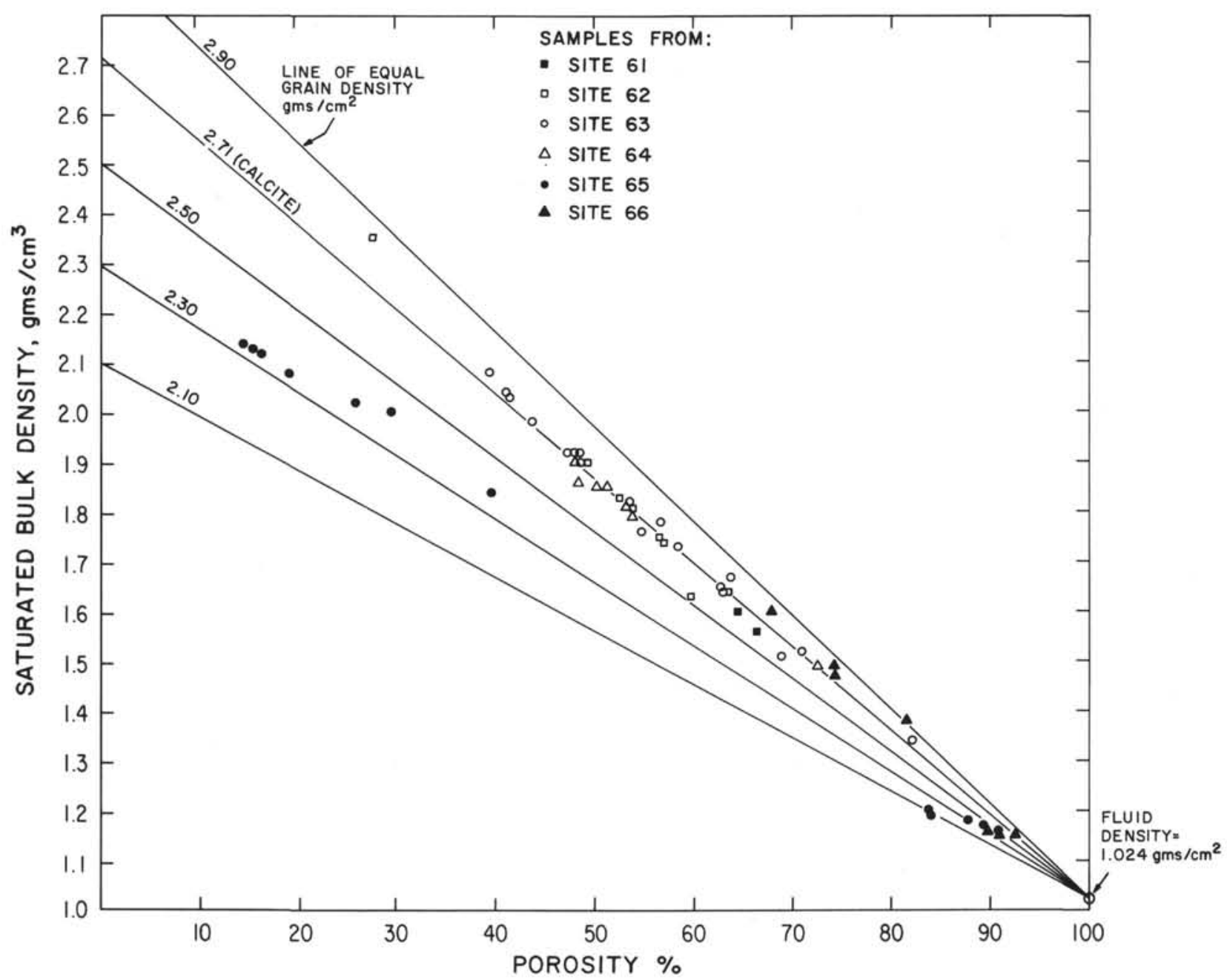

Figure 1. Saturated bulk density and porosity: shore laboratory samples, Western Equatorial Pacific (shore based measurements).

Measurements of grain density and values computed from measurements of saturated bulk density, porosity, and fluid density are shown in Table 1. The measured grain densities appear to match the values expected from knowledge of the mineralogy (Clark, 1966) and also have a high degree of consistency, indicating that they represent the true grain density more reliably than do the derived values. It is probable that the differences between the two sets of values result primarily from errors in measurements of saturated bulk density and porosity, and the most likely source of error is in estimating the volume of the samples.

Values of grain density derived from measurements of specific gravity by Jolly balance and porosity are higher than the measured values of grain density by +0.01 to $+0.07 \mathrm{gm} / \mathrm{cm}^{3}$, for all eight samples where both were determined. Values of grain density derived from measurements of saturated bulk density by the tube method were higher $\left(\leqslant+0.16 \mathrm{gm} / \mathrm{cm}^{3}\right)$ for twenty-three of thirty-four samples where both were determined, and were lower $\geqslant 0.19 \mathrm{gm} / \mathrm{cm}^{3}$ ) for eleven of the thirty-four.

\section{DISCUSSION: TECHNIQUES FOR DETERMINING SATURATED BULK DENSITY}

\section{Comparison: Values of Saturated Bulk Density by Gamma Ray Attenuation and by Net Section Weight Methods}

In order to compare values of saturated bulk density derived from measurements of gamma ray attenuation with values derived by dividing the net weight of a core section by its volume, the average of all values of the former obtained for each section were plotted against the latter for sets of all sections at each of the Sites 62, 63, 64, 65 and 66 (Figure 3), and for all values at all of these sites (Figure 4). 


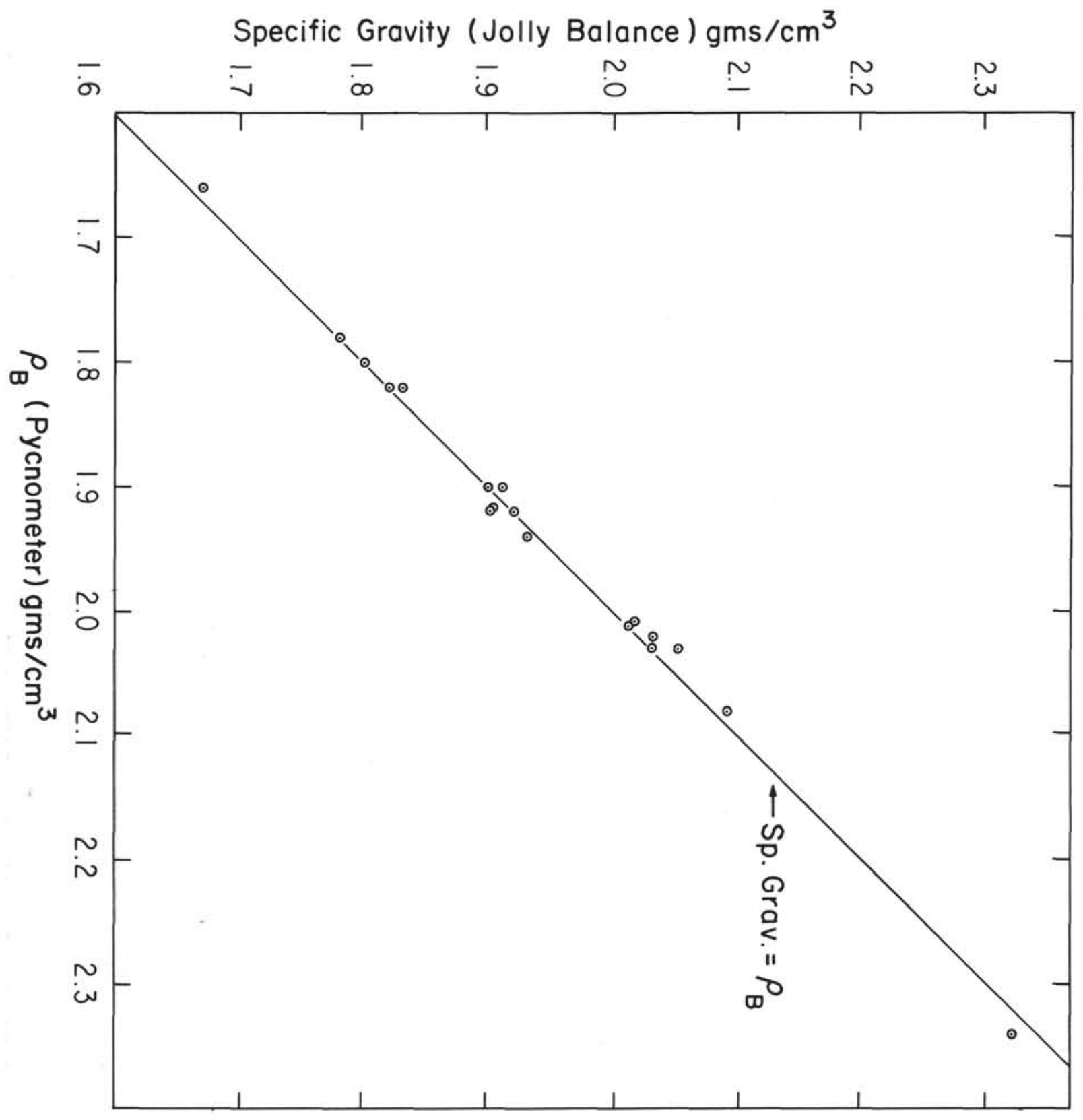

Figure 2. Comparison of specific gravity (Jolly balance) with saturated bulk density (pycnometer).

A least squares regression of the data yielding an equation of the form:

$$
\mathrm{Y}=\mathrm{AX}+\mathrm{B},
$$

where:

$\mathrm{X}=$ saturated bulk density by gamma ray attenuation (average of all values per section),

and:

$\mathrm{Y}=$ saturated bulk density by section weight was calculated for all pairs of samples at Sites 62, 63, 64, 65 and 66, and for pairs from all of these sites. The standard deviations of A and B were determined, and the standard error of estimate was determined for $\mathrm{X}$ and $\mathrm{Y}$ where $\mathrm{X}=\mathrm{Y}$ for all pairs at all of these sites (Table 2). Statistical techniques are after Dixon and Massey (1957). Both the line determined by least squares regression and the line $\mathrm{X}=\mathrm{L}$ are shown on Figures 3 and 4 .

Values of saturated bulk density derived from gamma ray attenuation are slightly higher on the whole 
TABLE 2

Comparison of Arrays of Values of Saturated Bulk Density by

Gamma Ray Attenuation (X) and by Net Section Weight (Y)

\begin{tabular}{|c|c|c|c|c|c|c|c|}
\hline \multirow[b]{3}{*}{ Site } & \multirow[b]{3}{*}{$\begin{array}{l}\text { Dominant } \\
\text { Lithology }\end{array}$} & \multirow[b]{3}{*}{$\begin{array}{l}\text { No. } \\
\text { Pts. }\end{array}$} & \multicolumn{4}{|c|}{$\begin{array}{c}\text { Values of A and B Calculated by } \\
\text { Least Squares Regression for } \\
Y=A X+B\end{array}$} & \multirow[t]{3}{*}{$\begin{array}{l}\text { Standard Error of Estimate } \\
\text { for } \mathrm{X} \text { and } \mathrm{Y}\end{array}$} \\
\hline & & & \multicolumn{2}{|c|}{$\mathrm{A}$} & \multicolumn{2}{|c|}{ B } & \\
\hline & & & Value & Std. Dev. & Value & Std. Dev. & \\
\hline 62 & Chalk-ooze & 166 & +1.061 & 0.048 & -0.132 & 0.028 & $0.073 \mathrm{gm} / \mathrm{cm}^{3}$ \\
\hline 63 & Chalk-ooze & 89 & +1.005 & 0.016 & -0.025 & 0.010 & $0.044 \mathrm{gm} / \mathrm{cm}^{3}$ \\
\hline 64 & Chalk-ooze & 56 & +1.113 & 0.030 & -0.227 & 0.017 & $0.036 \mathrm{gm} / \mathrm{cm}^{3}$ \\
\hline 65 & Radiolarian ooze & 30 & +0.249 & 0.078 & +0.891 & 0.065 & $0.035 \mathrm{gm} / \mathrm{cm}^{3}$ \\
\hline 66 & $\begin{array}{l}\text { Radiolarian ooze } \\
\text { and pelagic clay }\end{array}$ & 23 & +1.022 & 0.015 & -0.065 & 0.012 & $0.041 \mathrm{gm} / \mathrm{cm}^{3}$ \\
\hline \multicolumn{2}{|c|}{$\begin{array}{l}\text { Composite, Sites } 62,63 \text {, } \\
64,65 \text { and } 66\end{array}$} & 364 & +0.993 & 0.010 & -0.013 & \pm 0.006 & $0.058 \mathrm{gm} / \mathrm{cm}^{3}$ \\
\hline
\end{tabular}

$\left(+0.013 \mathrm{gm} / \mathrm{cm}^{3}\right.$ for composite) than those derived from section weight, but the difference is small when compared with errors in measurement. The systematic differences may result from the fact that most sections have a thin layer of sea water or drilling slurry around the core adjacent to the material, and in softer materials, there is often an air bubble along the top of the section as it is held horizontally. Both of these factors would tend to cause the section weight to be somewhat low. However, because the gamma ray attenuation device scans the material across the maximum diameter of the core, the effect of the slurry is minimized and a more representative sediment mass is measured.

There appears to be no significant variation in the validity of the two methods from one sediment type to another. The least squares regression by site for all sites shows standard deviations for A and B greater than those for the composite, probably because, together, samples from all sites present a wider range of values. At Site 65 , in particular, the difference between the highest and lowest saturated bulk density measured is small, and there is little doubt that the least squares regression calculated does not represent the sediment as a whole.

At Site 62, results from the two methods appear to differ significantly for two groups of samples. In one group, values from gamma ray attenuation are markedly higher than their section weight equivalents, probably because the sections were less than full. In the other group, gamma ray attenuation measurements are considerably lower than their section weight equivalent, probably because the sections were more than 150 centimeters in length. In both cases, values of saturated bulk density from gamma ray attenuation are most likely to be correct.

\section{Comparison: Saturated Bulk Density from Gamma Ray Attenuation Versus Values Derived from Measurements on Samples}

In order to evaluate laboratory measurements of saturated bulk density made aboard ship and ashore, values obtained were compared with those derived from measurements by gamma ray attenuation. The midpoint of each interval sampled for laboratory measurement, both aboard ship and ashore, was noted. All values of saturated bulk density derived from gamma ray attenuation measurements in an interval between 1.5 centimeters above and 1.5 centimeters below this midpoint were averaged. The values from shipboard measurements were plotted against values from gamma ray attenuation data by site for Sites 62 through 66 (Figure 5) and for all values at all of these sites (Figure 6). Similarly, the values from shore based measurements were plotted against values from gamma ray attenuation data by site for Sites 62 through 66, and these are shown on Figures 7 and 8.

A least squares regression of the data yielding an equation of the form:

$$
\mathrm{Y}=\mathrm{AX}+\mathrm{B} \text {, }
$$

where:

$\mathrm{X}=$ saturated bulk density by gamma ray attenuation, 


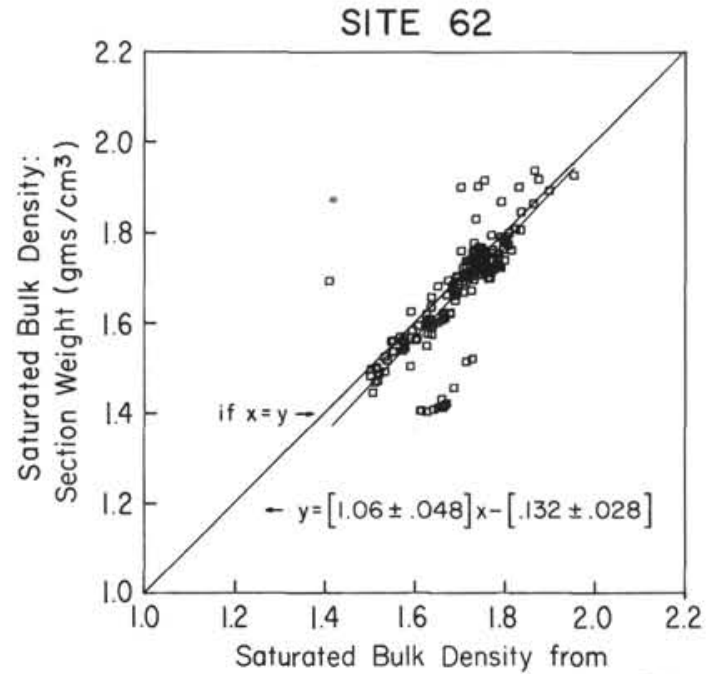

Gamma Ray Attenuation; ( $\mathrm{gms} / \mathrm{cm}^{3}$ )

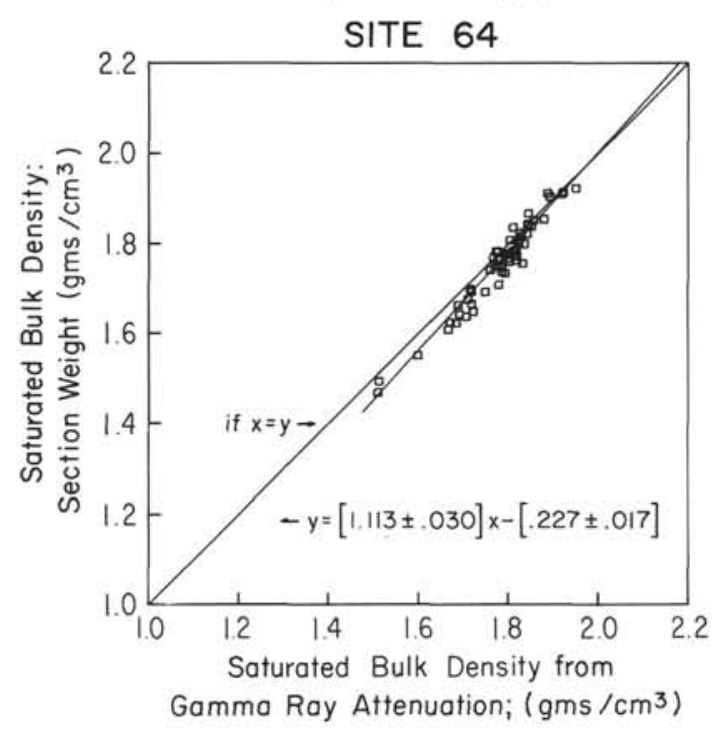

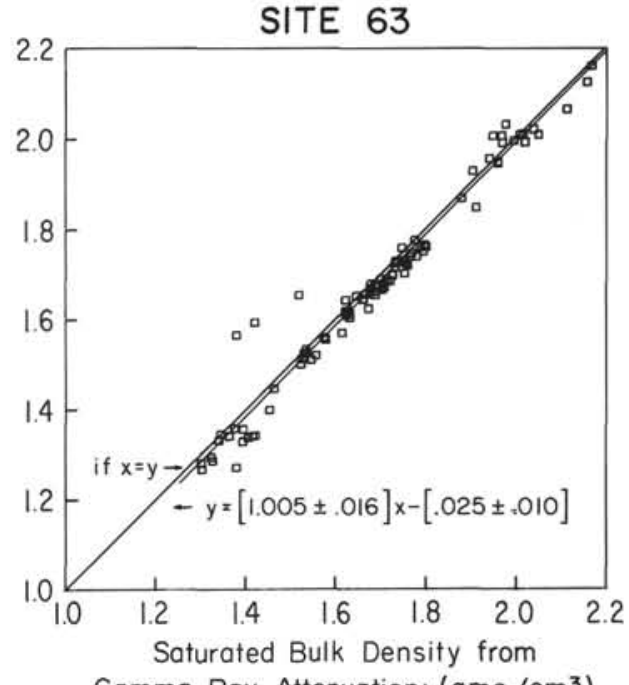

Gamma Ray Attenuation; ( $\mathrm{gms} / \mathrm{cm}^{3}$ )

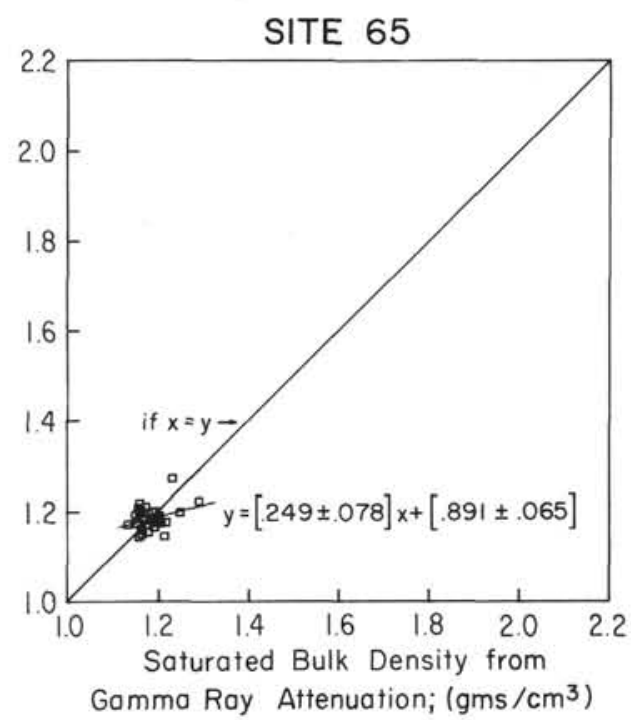

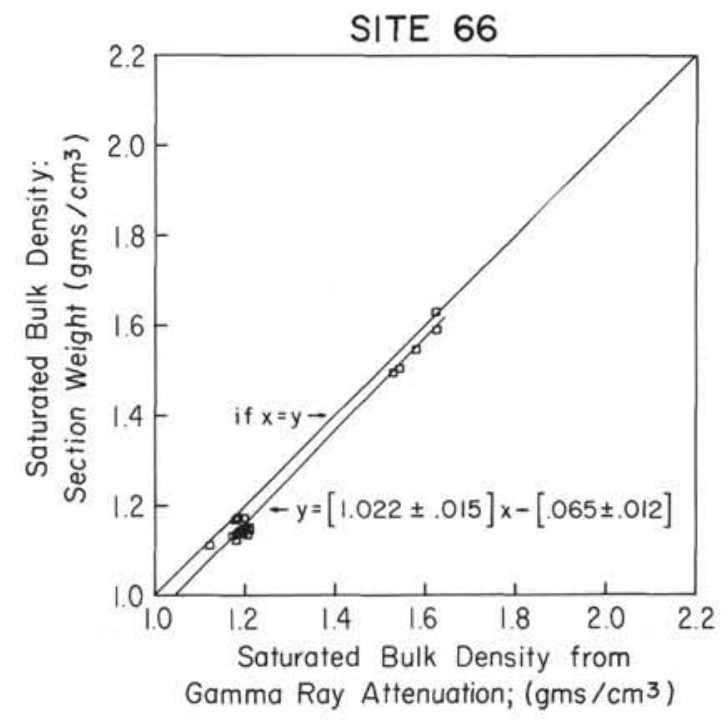

Figure 3. Comparison of values of saturated bulk density by gamma ray attenuation and by net section weight methods for sections from Sites 62, 63, 64, 65 and 66. 


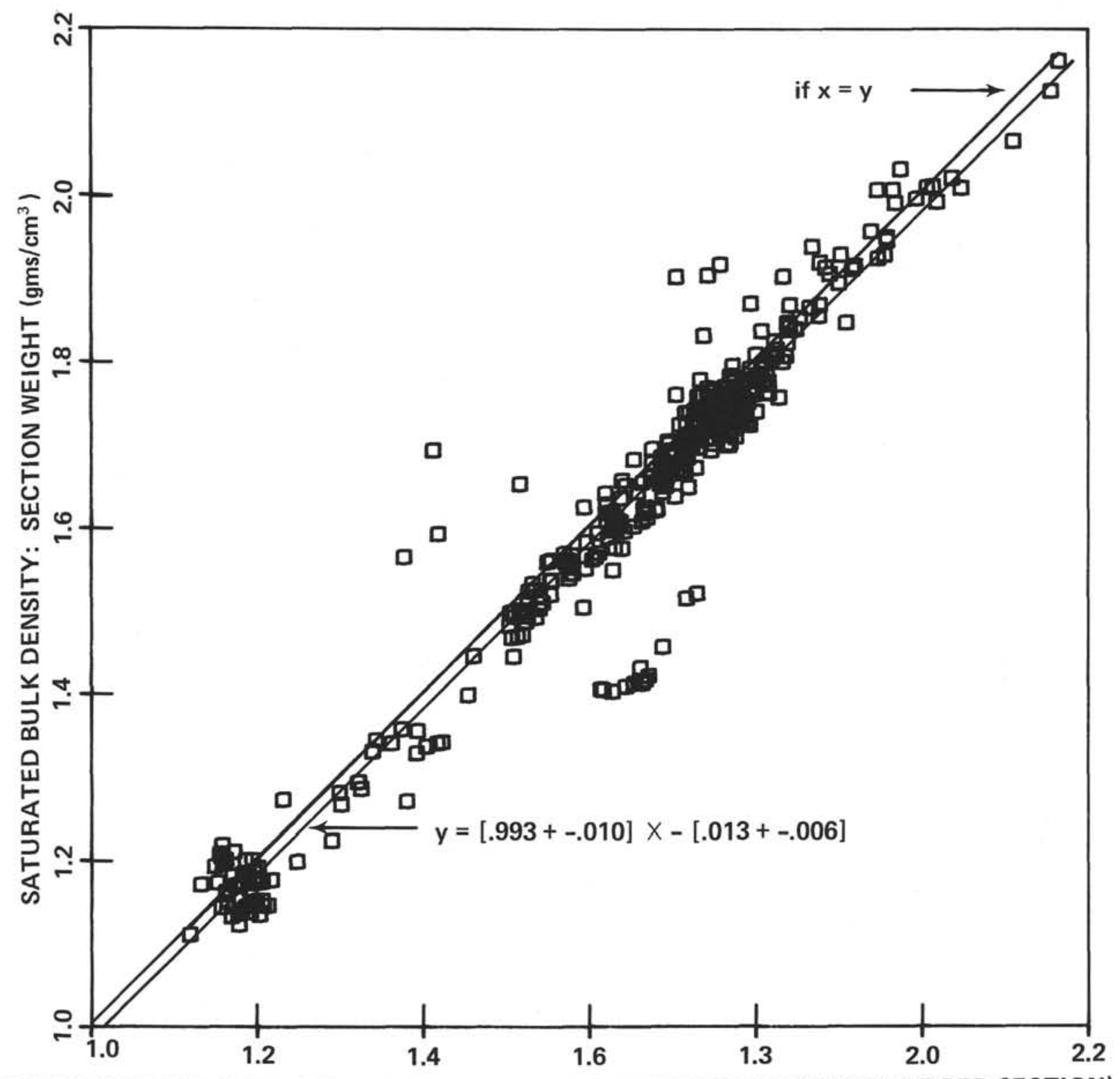

SATURATED BULK DENSITY FROM GAMMA RAY ATTENUATION (AVERAGE PER SECTION)

Figure 4. Comparison of values of saturated bulk density by gamma ray attenuation and by net section weight methods: composite of all sections from Sites 62,63, 64, 65 and 66.

and:

$\mathrm{Y}=$ saturated bulk density by laboratory measurement

was calculated for all pairs of samples at Sites 62 , $63,64,65$ and 66 and for pairs from all of these sites. The standard deviations of $\mathrm{A}$ and $\mathrm{B}$ were determined. The standard error of estimate was determined for $\mathrm{X}$ and $\mathrm{Y}$ when $\mathrm{X}=\mathrm{Y}$ for all pairs at all of these sites (Table 4). Both the line determined by least squares regression and the line $\mathrm{X}=\mathrm{Y}$ are shown on Figures 5 , 6,7 and 8 .
The wide scatter in the pairs of data is primarily due to the fact that the samples on which laboratory measurements were made are not identical to that part of the core scanned by the gamma ray attenuation device. Also, the scatter is wider for the samples taken ashore than those taken aboard ship, probably because the cores shift in transit, making a depth correlation with shipboard gamma ray attenuation records even less reliable.

Despite the scatter, it can be seen that the measurements of saturated bulk density of the samples are, in 

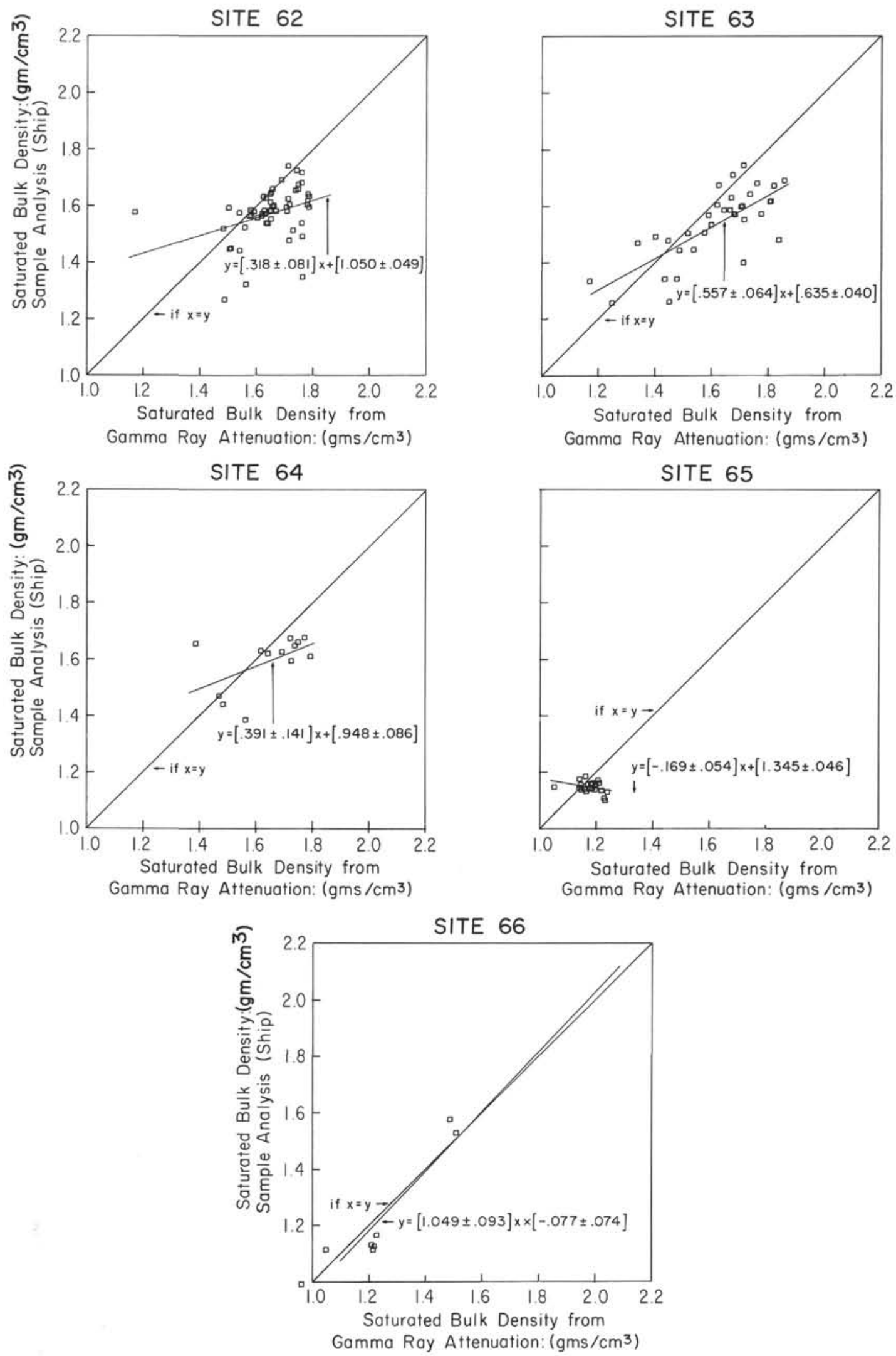

Figure 5. Comparison of values of saturated bulk density by gamma ray attenuation and by values derived from measurements (shipboard) on samples from Sites 62, 63, 64, 65 and 66. 


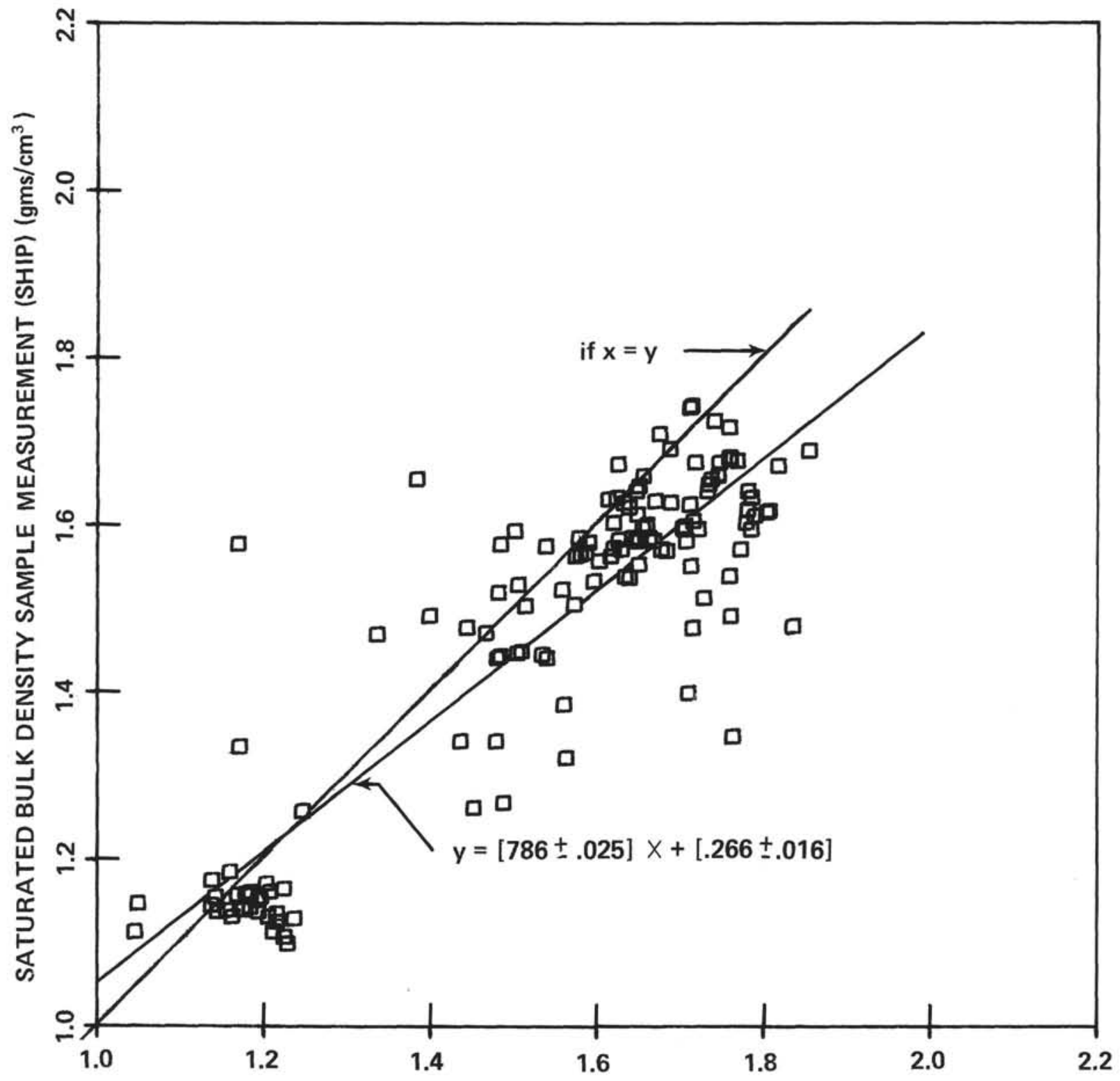

SATURATED BULK DENSITY FROM GAMMA RAY ATTENUATION (AVERAGE PER SECTION) $\left(\mathrm{gm} / \mathrm{cm}^{3}\right)$

Figure 6. Comparison of values of saturated bulk density by gamma ray attenuation and by values derived from measurements (shipboard) on samples: composite of all samples analyzed from Sites 62, 63, 64, 65 and 66.

most cases, less than the values derived from gamma ray attenuation. This is probably related to the fact that in more consolidated materials it is difficult to secure a sample free of cracks and holes, and that, in some sediment, particularly those containing layers of more and less consolidated materials, the method of sampling preferentially removes more plastic materials which are often less dense than the core as a whole. More of the measurements of saturated bulk density from samples made at sea are low with respect to those from gamma ray attenuation measurements than are those from samples taken ashore. This difference is probably related to the fact that the diameter of the tubes used to take samples on shore was greater than that of tubes used at sea, and the larger samples are more representative of the sediment cored. It is also possible that the cores dried somewhat between the time that the samples were taken at sea and the others were taken on shore.

\section{RESULTS}

Results of all measurements and derived values of saturated bulk density and porosity are plotted on the graphic Site Summaries and the core description charts 

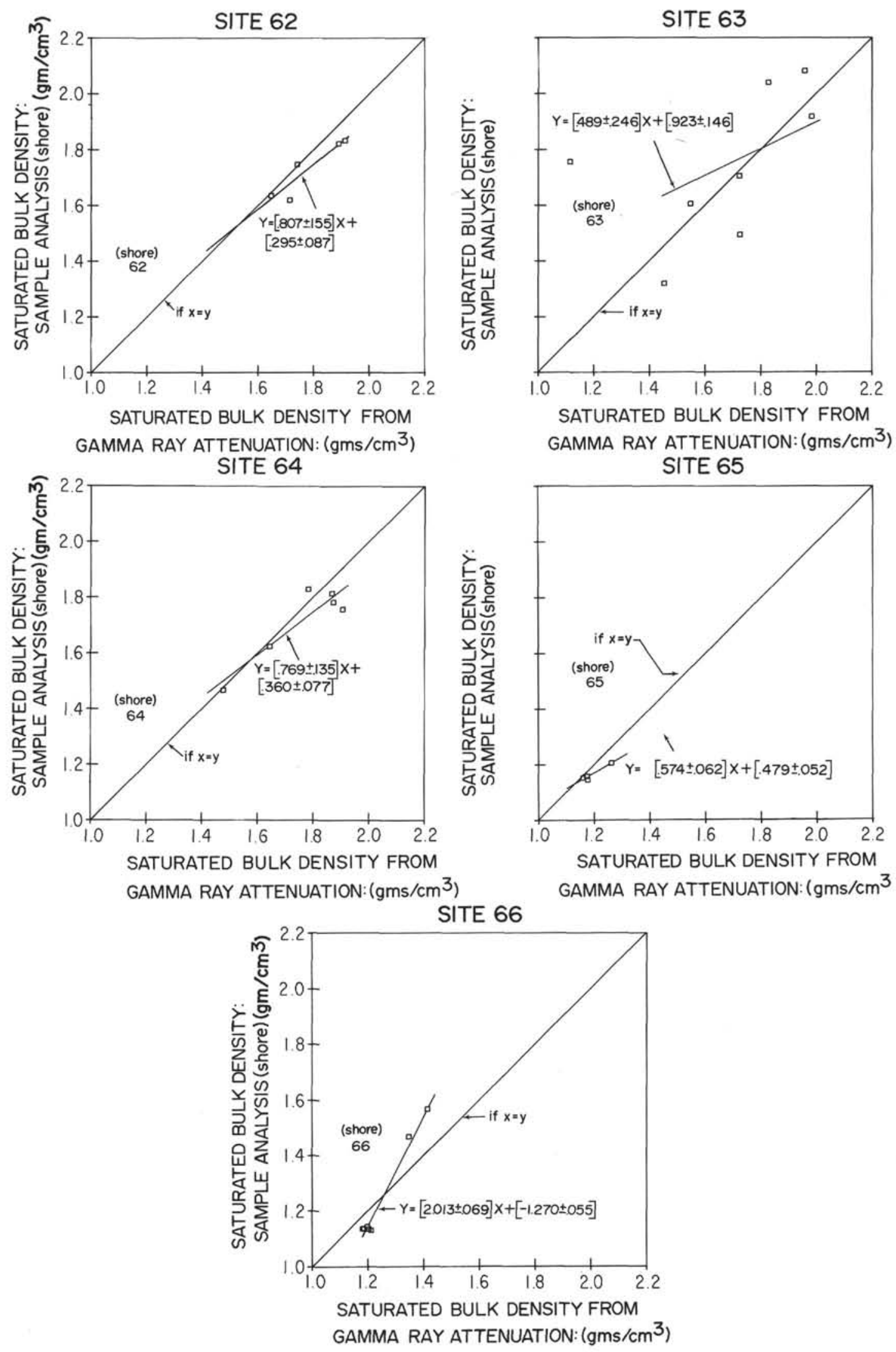

Figure 7. Comparison of values of saturated bulk density by gamma ray attenuation and by values derived from measurements (shore) on samples from Sites 62, 63, 64, 65 and 66. 


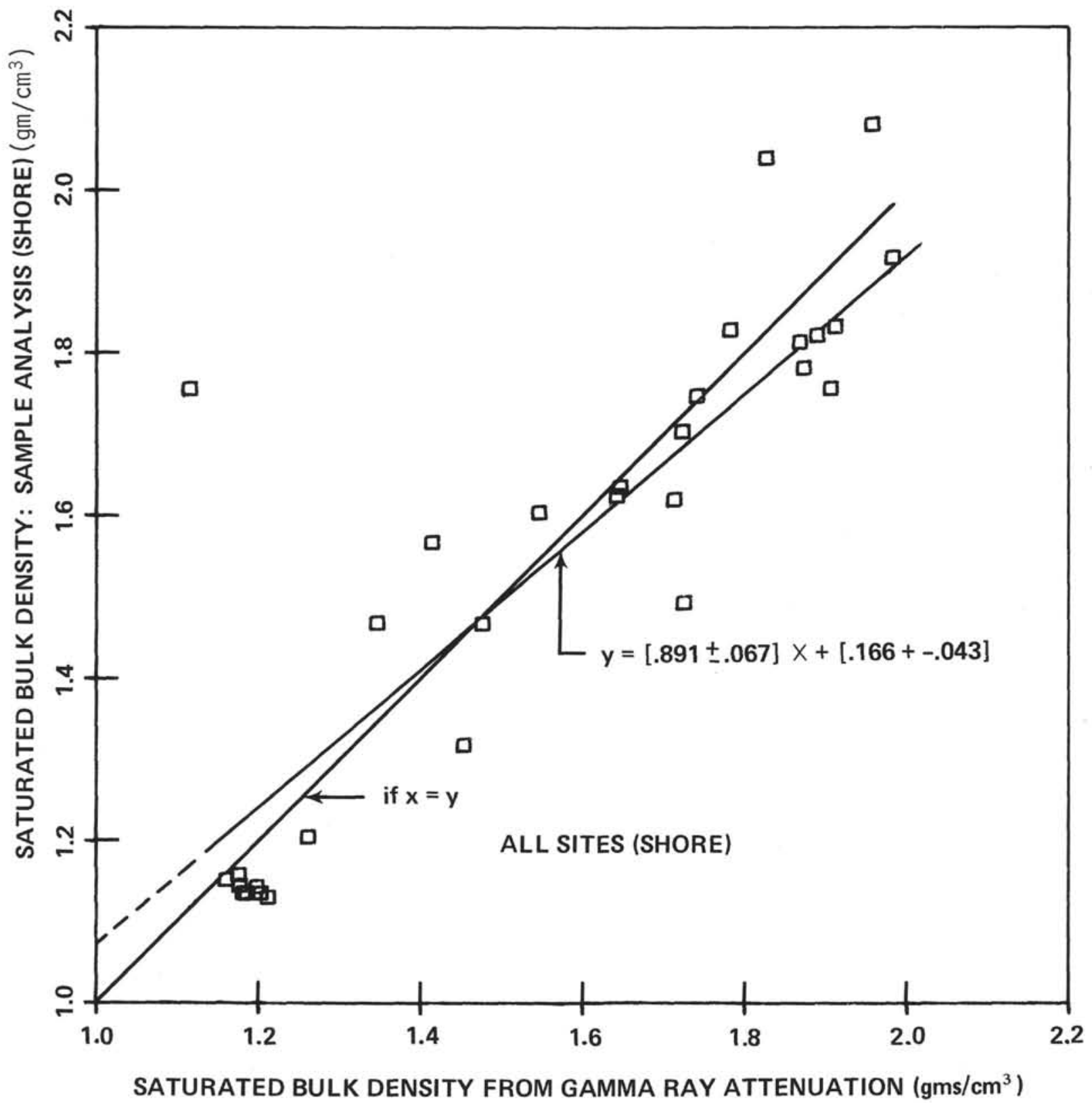

Figure 8. Comparison of values of saturated bulk density by gamma ray attenuation and by values derived from measurements (shore) on samples: composite of all samples analyzed from Sites 62, 63, 64, 65 and 66.

in Chapters 3 through 9. The results of shore laboratory measurements of saturated bulk density, porosity and grain density, together with some values of saturated bulk density by section weight and by gamma ray attenuation, are given in Table 1. The results, by site, are summarized below:

\section{Site 61}

At Site 61 , only 21 feet of core were recovered. Because of drilling disturbances, measurements of physical properties were practical only on 61.1-1, a core consisting of an Upper Cretaceous stiff mud containing fragments of consolidated cristobalitic porcelanite. Two samples of porcelanite from 61.1-1-2 were analyzed. Both had a mean grain density of 2.64 $\mathrm{gm} / \mathrm{cm}^{3}$. One had a saturated bulk density of 1.60 $\mathrm{gm} / \mathrm{cm}^{3}$ and a porosity of 64.4 per cent; the other had a saturated bulk density of $1.56 \mathrm{gm} / \mathrm{cm}^{3}$ and a porosity of 65.2 per cent.

\section{Site 62}

The two holes at Site 62 penetrated more than 500 meters of very pure nannofossil ooze-chalk-limestone, Late Oligocene and Quaternary, with a sugary dolomite 
TABLE 3

Comparison of Arrays of Values of Saturated Bulk Density by Gamma Ray Attenuation and by Measurements on Samples

\begin{tabular}{|c|c|c|c|c|c|c|c|c|c|c|c|c|c|}
\hline \multirow[b]{3}{*}{ Site } & \multirow[b]{3}{*}{$\begin{array}{l}\text { Dominant } \\
\text { Lithology }\end{array}$} & \multirow[b]{3}{*}{$\begin{array}{l}\text { No. } \\
\text { Pts. }\end{array}$} & \multicolumn{4}{|c|}{$\begin{array}{l}\text { Shipboard Measurements } \\
\text { Values of A and B Calculated } \\
\text { by Least Squares Regression } \\
\text { for } \mathrm{Y}=\mathrm{AX}+\mathrm{B}\end{array}$} & \multirow[t]{3}{*}{$\begin{array}{l}\text { Standard Error } \\
\text { of Estimate for } \\
\mathrm{X} \text { and } \mathrm{Y}\end{array}$} & \multirow[b]{3}{*}{$\begin{array}{l}\text { No. } \\
\text { Pts. }\end{array}$} & \multicolumn{4}{|c|}{$\begin{array}{l}\text { Shore Measurements } \\
\text { Values of A and B Calculated } \\
\text { by Least Squares Regression } \\
\text { for } \mathrm{Y}=\mathrm{AX}+\mathrm{B}\end{array}$} & \multirow[t]{3}{*}{$\begin{array}{l}\text { Standard Error } \\
\text { of Estimate for } \\
\mathrm{X} \text { and } \mathrm{Y}\end{array}$} \\
\hline & & & \multicolumn{2}{|c|}{$\mathrm{A}$} & \multicolumn{2}{|r|}{$B$} & & & \multicolumn{2}{|c|}{$\mathrm{A}$} & \multicolumn{2}{|r|}{$B$} & \\
\hline & & & Value & Std. Dev. & Value & Std. Dev. & & & Value & Std. Dev. & Value & Std. Dev. & \\
\hline 62 & Chalk-ooze & 55 & 0.318 & 0.081 & +1.050 & 0.049 & $0.133 \mathrm{gm} / \mathrm{cm}^{3}$ & 5 & 0.807 & 0.155 & 0.295 & 0.087 & $0.063 \mathrm{gm} / \mathrm{cm}^{3}$ \\
\hline 63 & Chalk-ooze & 35 & 0.557 & 0.064 & +0.635 & 0.040 & $0.131 \mathrm{gm} / \mathrm{cm}^{3}$ & 8 & 0.489 & 0.246 & 0.923 & 0.146 & $0.244 \mathrm{gm} / \mathrm{cm}^{3}$ \\
\hline 64 & Chalk-ooze & 14 & 0.392 & 0.141 & +0.948 & 0.086 & $0.120 \mathrm{gm} / \mathrm{cm}^{3}$ & 6 & 0.769 & 0.135 & 0.360 & 0.077 & $0.077 \mathrm{gm} / \mathrm{cm}^{3}$ \\
\hline 65 & $\begin{array}{l}\text { Radiolarian } \\
\text { ooze }\end{array}$ & 23 & -0.169 & 0.054 & +1.345 & 0.046 & $0.059 \mathrm{gm} / \mathrm{cm}^{3}$ & 4 & -0.574 & 0.062 & 0.479 & 0.052 & $0.029 \mathrm{gm} / \mathrm{cm}^{3}$ \\
\hline 66 & $\begin{array}{l}\text { Radiolarian } \\
\text { ooze and } \\
\text { pelagic clay }\end{array}$ & 8 & 1.049 & 0.093 & -0.077 & 0.074 & $0.069 \mathrm{gm} / \mathrm{cm}^{3}$ & 7 & 2.013 & 0.069 & -1.270 & 0.055 & $0.075 \mathrm{gm} / \mathrm{cm}^{3}$ \\
\hline \multicolumn{2}{|c|}{$\begin{array}{l}\text { Composite, Sites } \\
62,63,64,65,66\end{array}$} & 135 & 0.786 & 0.025 & 0.266 & 0.016 & $0.120 \mathrm{gm} / \mathrm{cm}^{3}$ & 30 & 0.891 & 0.067 & 0.166 & 0.043 & $0.149 \mathrm{gm} / \mathrm{cm}^{3}$ \\
\hline
\end{tabular}


TABLE 4

Comparison of Values of Mean Grain Density, Saturated Bulk Density, and Porosity from Measurements on Samples of Chalk and Adjacent Drilling Paste

\begin{tabular}{|c|c|c|c|c|c|c|c|}
\hline Hole & Core & Section & $\begin{array}{l}\text { Interval } \\
(\mathrm{cm})\end{array}$ & Nature & $\begin{array}{c}\rho_{\mathrm{g}} \\
\text { (Measured) } \\
\mathrm{gm} / \mathrm{cm}^{3}\end{array}$ & $\begin{array}{c}\rho_{\mathrm{B}} \\
\text { (Measured) } \\
\mathrm{gm} / \mathrm{cm}^{3}\end{array}$ & $\begin{array}{c}\phi \\
\text { (Derived) } \\
\text { Per Cent }\end{array}$ \\
\hline \multirow[t]{3}{*}{62.0} & 4 & 2 & $139.0-141.0$ & Biscuit & 2.654 & 1.820 & 53.30 \\
\hline & & & $142.0-144.5$ & Paste & 2.679 & 1.713 & 55.47 \\
\hline & & & & Difference & +0.025 & -0.007 & +2.17 \\
\hline \multirow[t]{3}{*}{63.0} & 4 & 1 & $118.5-121.0$ & Biscuit & 2.731 & 1.780 & 55.86 \\
\hline & & & $50.5-53.0$ & Paste & 2.682 & 1.755 & 54.09 \\
\hline & & & & Difference & -0.049 & -0.025 & -1.77 \\
\hline \multirow[t]{3}{*}{63.0} & 5 & 1 & $17.5-19.5$ & Biscuit & 2.732 & 1.830 & 53.03 \\
\hline & & & $89.0-91.5$ & Paste & 2.732 & 1.888 & 45.92 \\
\hline & & & & Difference & 0.000 & +0.058 & -7.11 \\
\hline \multirow[t]{3}{*}{63.0} & 7 & 1 & $12.5-14.0$ & Biscuit & 2.724 & 1.920 & 47.36 \\
\hline & & & $52.5-55.0$ & Paste & 2.708 & 1.944 & 42.49 \\
\hline & & & & Difference & -0.016 & +0.024 & -4.87 \\
\hline \multirow[t]{3}{*}{63.0} & 9 & 1 & $12.0-14.5$ & Biscuit & - & 2.050 & 40.65 \\
\hline & & & $48.0-50.5$ & Paste & 2.733 & 1.986 & 40.15 \\
\hline & & & & Difference & & -0.064 & -0.50 \\
\hline
\end{tabular}

overlying basalt at the base. The upper 360 meters of the section were continuously cored and saturated bulk density measurements were made on almost all sections recovered.

Measurements of mean grain density were made on eight samples from Site 61. Values in the nannofossil ooze-chalk-limestone sequence ranged from 2.65 to $2.71 \mathrm{gm} / \mathrm{cm}^{3}$, and all but one were within the experimental error of \pm 0.03 of the $2.71 \mathrm{gm} / \mathrm{cm}^{3}$, the density of calcite (Robie et al., 1966). Therefore, for purposes of computing porosity from saturated bulk density measurements, a grain density of $2.71 \mathrm{gm} / \mathrm{cm}^{3}$ was assigned to all sections at Site 62 in the nannofossil ooze-chalk-limestone sequence. The mean grain density of 2.86 derived from measurements of saturated bulk density and porosity of a dolomite sample from 62.0-7-1 matches that of dolomite (Robie et al., 1966).

At Site 62, values of saturated bulk density derived from gamma ray attenuation yield values about the same as or somewhat higher and show greater consistency than do measurements of saturated bulk density of samples.

The saturated bulk density of the nannofossil oozechalk sequence increases irregularly from $1.5 \mathrm{gm} / \mathrm{cm}^{3}$ at the surface (Quaternary) to about $1.73 \mathrm{gm} / \mathrm{cm}^{3}$ at 200 meters (Late Miocene). Below 200 meters, it increases at a slower rate to $1.90 \mathrm{gm} / \mathrm{cm}^{3}$ at 500 meters (Early Miocene). At a grain density of 2.71 $\mathrm{gm} / \mathrm{cm}^{3}$, the porosity of the surface samples is about 71 per cent; of samples from 200 meters, about 58 per cent; and of samples from 500 meters, about 45 per cent. The dolomite recovered from $62.0-7-1$ had a grain density of $2.86 \mathrm{gm} / \mathrm{cm}^{3}$, a saturated bulk density of $2.35 \mathrm{gm} / \mathrm{cm}^{3}$, and a porosity of 27.8 per cent.

It should be noted that the tendency for saturated bulk density to increase with depth is not uniform and some reversals are present. For example, the interval 200 to 230 meters is more dense than the interval 230 to 290 . 
These reversals are also common on a small scale and a single core section may consist of alternating more and less dense layers.

\section{Site 63}

The sequence penetrated at Site 63 consists of an Early Oligocene to Late Miocene nannofossil ooze-chalklimestone overlain by 35 meters of Pliocene pelagic clay interbedded with marl.

Measurements of mean grain density were made on fifteen samples of the pelagic clay and the nannofossil ooze-chalk-limestone from Site 63 . Values range from 2.68 to 2.73 , all within the experimental error of \pm 0.03 of 2.71 , the density of calcite. For purposes of deriving porosity from measurements of saturated bulk density, a mean grain density of 2.71 was assigned to all sections at this site.

The pelagic clay has a saturated bulk density of 1.38 $\mathrm{gm} / \mathrm{cm}^{3}$ and a porosity of about 80 per cent.

The underlying nannofossil ooze at 65 meters has a saturated bulk density of 1.70 , and a porosity of 60 per cent. The chalk ooze in the interval 100 to 135 meters has a lower saturated bulk density $(1.55$ $\left.\mathrm{gm} / \mathrm{cm}^{3}\right)$ and higher porosity (65 per cent) than the overlying material. The fact that most of the sections recovered in this interval are not badly disturbed suggests that the low saturated bulk density in this interval is real. Below this interval, the saturated bulk density increases abruptly to about $1.80 \mathrm{gm} / \mathrm{cm}^{3}$, and the increase corresponds to a level where the drilling rate decreased from about $150 \mathrm{ft} / \mathrm{hr}$ to about $20 \mathrm{ft} / \mathrm{hr}$. Visual examination of the cores shows alternating layers of more and less lithified material.

There is an interval of slightly lower saturated bulk density between 180 and 190 meters $\left(\rho_{\mathrm{B}}=1.78\right)$. Below this horizon, coring was more sparse, but there appears to be a continuous increase in saturated bulk density to about $2.16 \mathrm{gm} / \mathrm{cm}^{3}$ in an Early Oligocene chalk at 560 meters (porosity: 35 per cent).

\section{Site 64}

Two holes at Site 64 penetrated nearly a kilometer of very pure Middle Eocene to Quaternary nannofossil ooze-chalk-limestone. The details of the variations in saturated bulk density with depth are unknown throughout most of the section because the only continuous coring was between 430 and 480 meters in Hole 64.1.

Nine measurements of mean grain density were made of samples from Site 64, and values range from 2.63 to 2.72 . Except for one value, all were within the experimental error of \pm 0.03 of the density of calcite,
2.71 (Robie et al., 1966). This value was used for purposes of calculating porosity from saturated bulk density for all sections at this site.

The porosity decreases rapidly from about 72 per cent in Quaternary oozes near the surface to 60 per cent at 200 meters (Late Miocene). Below that, it decreases more slowly and irregularly to about 50 per cent $\left(\rho_{B}=\right.$ 1.85) at 970 meters (Middle Eocene). Penetration of the top of the Early Miocene at about 430 meters marked the beginning of more difficult drilling, but this harder material was not substantially more dense than the overlying material.

Foraminifera tests constitute an important part of the sediment, and there appears to be a correlation between high porosity and high foraminifera content.

\section{Site 65}

Holes at Site 65 penetrated 187 meters of radiolarian ooze interbedded in the bottom 60 meters with calcareous ooze, porcelanite and silicified turbidites.

Measurements of mean grain density were made on five samples in the radiolarian ooze. Values ranged from 2.03 to $2.34 \mathrm{gm} / \mathrm{cm}^{3}$, and show an orderly decrease with depth in the hold (Figure 9). The radiolarian ooze at Site 66 similarly shows a decrease in grain density with depth. The ooze at both Sites 65 and 66 consists almost entirely ( 90 per cent and more) of opaline skeletal material. The decrease in mean grain density with depth could result either from a decrease in the amount of non-opaline material of high density with depth, or from a decrease in the bulk density of the opaline material itself.

Postulating that this change in mean grain density might be related to decrease in the non-opaline skeletal component of the ooze with depth, and that the non-opaline fraction might consist mostly of smallersized particles, all measured values of mean grain density of samples from both Sites 65 and 66 were plotted against the per cent clay size (Figure 10), and a relationship between the properties is seen to exist. The mean grain density of samples from both sites also increases as the proportion of sand sizes decreases. A least squares fit of $\mathrm{Y}=[70.2 \pm 11.4] \mathrm{X}$ $[110.0 \pm 4.7]$, where $Y=$ per cent clay size and $X=$ mean grain density, was determined. If clay sizes constitute 100 per cent of the sample, this relationship would yield a value of $\rho_{\mathrm{g}}=2.99 \mathrm{gm} / \mathrm{cm}^{3}$, which is not unreasonable. However, if clay sizes constitute zero per cent of the sample, the relationship would yield a value of $\rho_{\mathrm{g}}=1.57 \mathrm{gm} / \mathrm{cm}^{3}$, which is too low for any mineral constituent observed in samples from this site. Even highly hydrated opal has a grain density higher than this; the minimum density of opal reported by Winchell 


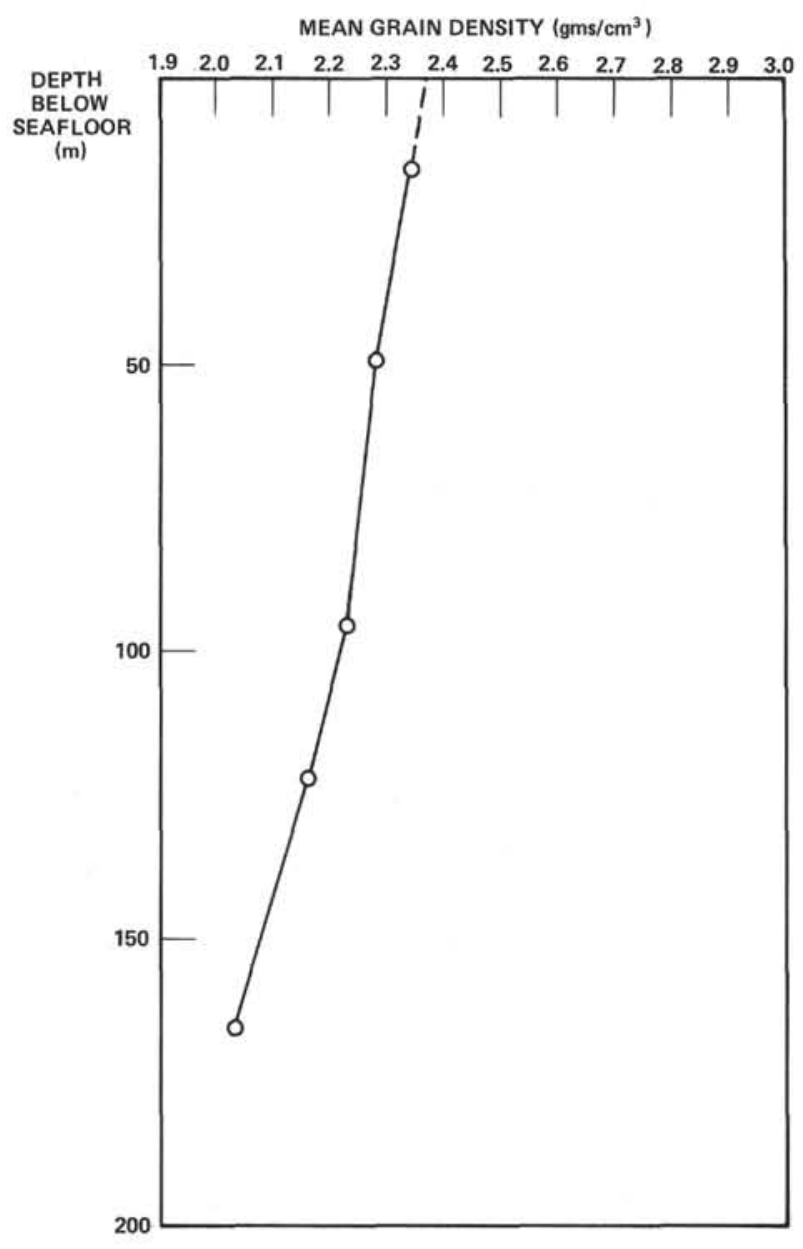

Figure 9. Mean grain density versus depth of samples from Site 65.

(1947) is $1.731 \mathrm{gm} / \mathrm{cm}^{3}$. It is possible that all values of the percentage clay size in the radiolarian oozes are too high, because the high specific surface area of the fragments of Radiolaria and other biogenous debris causes the particles to settle more slowly.

If the decrease in grain density is caused by a change in the proportion of non-opaline component with depth, a question arises concerning what this other component might be. Small amounts of iron and manganese oxides are present $\left(\rho_{\mathrm{g}} \sim 5.25\right)$, but if the opaline component has a grain density of 2.0 , more than 10 per cent of the sediment by volume would have to consist of these heavier minerals, and it does not. The alternative, that the opaline skeletal material may show a decrease in grain density because of an increase in the degree of hydration with depth, must be considered.

For purposes of calculating porosity from saturated bulk density measurements, the above relationship was used to interpolate values of mean grain density for which no measurement of grain density was made in the radiolarian ooze at both Sites 65 and 66 .

Measurements on cores show that the saturated bulk density of the radiolarian ooze at Site 65 decreases from $1.10 \mathrm{gm} / \mathrm{cm}^{3}$ (95 per cent porosity) in Quaternary at the surface to only $1.24 \mathrm{gm} / \mathrm{cm}^{3}$ ( 80 per cent porosity) at 123 meters (Late Eocene). If similar conditions pertain here as exist in the Caribbean (Gealy and Gerald, 1970), the in situ porosity of this ooze could be as low as 60 per cent.

Core recovery was poor in the interbedded calcareous and silicious ooze, porcelanites, and silicified turbidites below 123 meters, but intact cores at the top and bottom of the interval have saturated bulk density higher than the overlying material $\left(1.39 \mathrm{gm} / \mathrm{cm}^{3}\right.$ and porosity 68 per cent). Also, several pieces of porcelanite and silicified calcareous material from the core catcher sample of 65.0-17-cc and a brown impure chert from 65.1-6-cc were analyzed on shore. Saturated bulk density ranged from 2.0 to $2.13 \mathrm{gm} / \mathrm{cm}^{3}$; porosity ranged from 15.6 to 29.6 per cent. Values of mean grain density derived from saturated bulk density and porosity measurements ranged from 2.33 to 2.38 $\mathrm{gm} / \mathrm{cm}^{3}$.

\section{Site 66}

Holes at Site 66 penetrated a Quaternary to Early Miocene or Oligocene radiolarian ooze 130 to 160 meters thick. This is underlain by a Cretaceous pelagic clay 30 to 35 meters thick.

Measurements of mean grain density on five samples of radiolarian ooze ranged from 2.21 to $2.58 \mathrm{gm} / \mathrm{cm}^{3}$; on three samples of pelagic clay ranged from 2.74 to 2.80 $\mathrm{gm} / \mathrm{cm}^{3}$; and on one sample of volcanic mud was 2.89 $\mathrm{gm} / \mathrm{cm}^{3}$ (Figure 11). As at Site 65 , values of mean grain density in the radiolarian ooze decrease as the percentage of clay-sized particles decreases and as the percentage of sand-sized particles increases. The relationship $\mathrm{Y}=70.2 \mathrm{X} \cdot 110.0$, where $\mathrm{Y}=$ per cent clay size and $X=$ mean grain density, was used in assigning a mean grain density value to each interval for which no grain density measurement was made, for purposes of deriving porosity values from saturated bulk density measurements.

Measurements of saturated bulk density of samples from radiolarian ooze were remarkably uniform, ranging from $1.10 \mathrm{gm} / \mathrm{cm}^{3}$ (porosity: 94 per cent) at 15 meters to $1.18 \mathrm{gm} / \mathrm{cm}^{3}$ (porosity: 85 per cent) at 120 meters. As mentioned above, the porosities of deeper radiolarian ooze may be substantially greater in situ than were measured in the laboratory. 


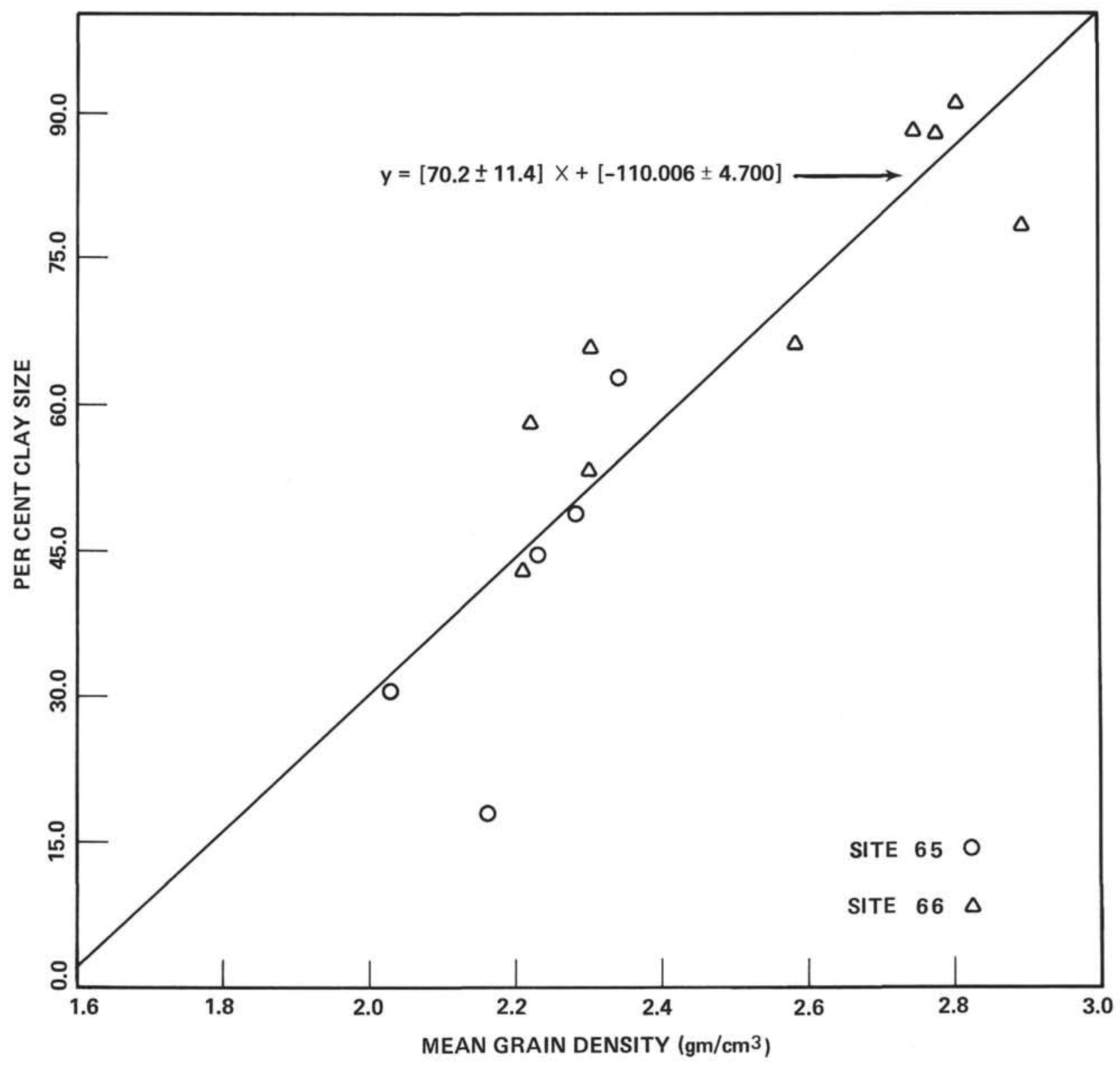

Figure 10. Mean grain density versus percentage clay size of samples from Sites 65 and 66.

In the pelagic clay, the values of mean grain density increase with depth, probably because of increasing content of ferromanganese minerals with depth.

The pelagic clay is more dense than the radiolarian ooze, with measurements of saturated bulk density ranging up to $1.64 \mathrm{gm} / \mathrm{cm}^{3}$ (porosity: 65 per cent). The porosity is lowest in the middile of the clay and increases somewhat toward the top and markedly toward the bottom. Cores in this interval were badly disturbed and the differences in porosity may be largely due to artifacts in drilling.

\section{Site 67}

No determinations of saturated bulk density, grain density or porosity were made on samples from Site 67.

\section{EFFECT OF PULVERIZING ON THE SATURATED BULK DENSITY OF CHALK}

In order to determine the effect of the pulverizing action of drilling on the saturated bulk density of chalk, five pairs of samples, one of chalk and the other an adjacent sample of drilling paste, were selected for analysis. The results are shown in Table 4 . In three of 


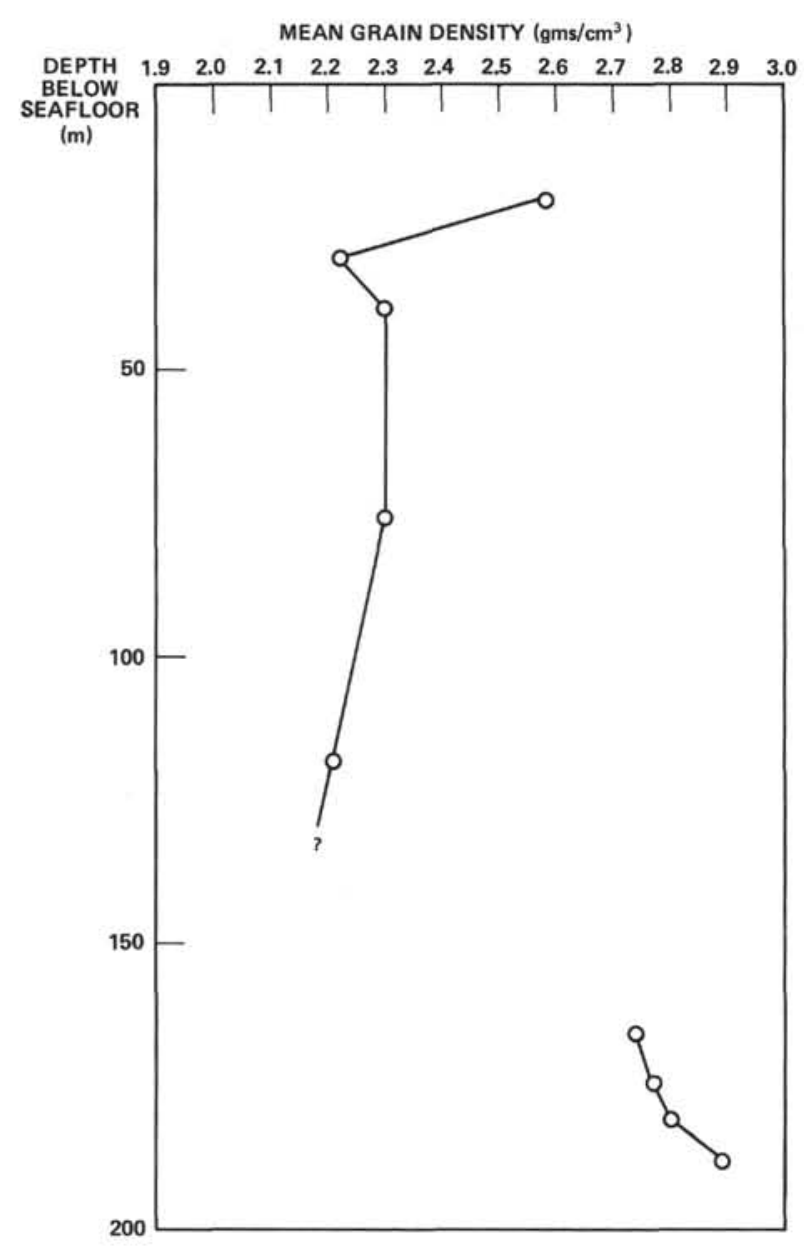

Figure 11. Mean grain density versus depth of samples from Site 66.

the five pairs, the pulverizing resulted in a decrease in porosity; in the other two, it results in an increase.

Chalk samples with the lowest porosity $(0.4065)$ and highest porosity (0.5506) showed the least change. Pulverizing samples destroys intergranular cementation, permitting samples having a porosity greater than a critical value dependent on the sorting (Graton and Fraser, 1935) to be compacted into a more dense configuration. However, drilling fluid may be admixed to an undetermined degree, and predictions of the effect of pulverizing on saturated bulk density of cored chalk are tenuous.

\section{SUMMARY AND CONCLUSIONS}

Saturated bulk density, grain density and porosity were determined on sediment cores from the Western Equatorial Pacific (Leg 7, Glomar Challenger) by several different techniques. Results by these techniques are presented, evaluated, and compared.
Leg 7 of the Glomar Challenger lacked the means for determining these properties in situ, and all determinations of saturated bulk density, grain density and porosity were made on cored materials in the laboratory.

Besides the systematic errors mentioned, the determination of saturated bulk density, grain density and porosity by measuring the weight and volume of samples is subject to errors of procedure and measurement.

Procedural errors result from sampling and handling methods. A serious error in measurement of saturated bulk density and porosity of samples derived from the fact that the sampling process selectively removes more plastic materials which are often less dense than the core as a whole. Samples may be incompletely saturated. Extraneous water or drilling fluid may fill cracks or holes in the samples, particularly in more consolidated materials. The samples may be insufficiently dried.

Measurement of weight, temperature, volume and estimates of salt content also result in error. Cumulatively, these result in errors of $\leqslant\left( \pm 0.01 \mathrm{gm} / \mathrm{cm}^{3}\right)$ in measurements of saturated bulk density by the tube method, pycnometer, or Jolly balance methods. They result in errors of $\leqslant( \pm 0.3$ per cent $)$ in measurements of porosity by the tube method or derived from the pycnometer or Jolly balance method. They result in errors of $\left( \pm 0.02 \mathrm{gm} / \mathrm{cm}^{3}\right)$ in measurements of grain density by the pycnometer method.

Two samples of porcelanite from Site 61 had a mean grain density of $2.64 \mathrm{gm} / \mathrm{cm}^{3}$. They had saturated bulk densities of 1.60 and $1.56 \mathrm{gm} / \mathrm{cm}^{3}$, and porosities of 64 and 65 per cent.

Holes at Sites 62, 63 and 64 penetrated sequences of nannofossil ooze-chalk-limestone as deep as 985 meters and as old as Middle Eocene. Except for samples from marly sequences and from a dolomite at the bottom of Hole 62.0, measured grain densities were $2.71 \pm 0.03$ $\mathrm{gm} / \mathrm{cm}^{3}$ throughout. The dolomite had a grain density of $2.86 \mathrm{gm} / \mathrm{cm}^{3}$.

The saturated bulk density of near surface Quaternary nannofossil oozes had a saturated bulk density of about $1.5 \mathrm{gm} / \mathrm{cm}^{3}$ and a porosity of 72 per cent at all three sites. The porosity decreases irregularly with depth at all three sites, and the rate of decrease appears to be related not only to depth of burial, but to age. For example, the saturated bulk density and porosity of Late Oligocene nannofossil ooze are almost identical 
at the three sites, as are those of Middle Miocene age, despite different depths of burial:

\begin{tabular}{l|c|c|c|c|c|c|c|c|c}
\hline & \multicolumn{3}{|c|}{ Site 62 } & \multicolumn{3}{c|}{ Site 63 } & \multicolumn{3}{c}{ Site 64 } \\
\cline { 2 - 9 } & Depth (m) & $\rho_{\mathrm{B}}$ & $\phi$ & Depth (m) & $\rho_{\mathrm{B}}$ & $\phi$ & Depth (m) & $\rho_{\mathrm{B}}$ & $\phi$ \\
\cline { 2 - 9 } Recent & 0 & 1.50 & 72 & 0 & 1.50 & 72 & 0 & 1.50 & 72 \\
Middle Miocene & 340 & 1.75 & 57 & 140 & 1.75 & 57 & 300 & 1.71 & 59 \\
Late Oligocene & 520 & 1.90 & 49 & 350 & 1.91 & 49 & 560 & 1.85 & 51 \\
\hline
\end{tabular}

At all three sites, important reversals (where porosity decreases with depth and then increases) which appear real and not artifacts are found on both the centimeter and decimeter scale. At Site 62 , the porosity is 54 per cent at 215 meters, and 60 per cent at 275 meters. At Site 63 , the porosity is 60 per cent at 65 meters, and 65 per cent or less at 120 meters. At Site 64 , the porosity is 50 per cent at 570 meters, and 54 per cent at 615 meters.

The mean grain density of the radiolarian ooze at Sites 65 and 66 decreases from about $2.35 \mathrm{gm} / \mathrm{cm}^{3}$ near the surface to $2.03 \mathrm{gm} / \mathrm{cm}^{3}$ or less near the base. Although a decrease in the non-opaline fraction of the ooze with depth may contribute to this change, an increase in the degree of hydration of the opal with depth remains a possibility. The porosity of the cores of radiolarian ooze decreases from about 90 per cent in the Recent surface materials at both sites to 80 per cent in Eocene materials (at 160 meters at Site 65, and 120 meters at Site 66). Porosities of the deeper radiolarian ooze may be as low as 60 per cent in situ.

The grain density of the pelagic clay at Site 66 increases from 2.74 to $2.89 \mathrm{gm} / \mathrm{cm}^{3}$ with depth in the clay, probably because of an increase with depth in the amount of iron and manganese oxides present. Cores of the clay were badly disturbed and inference of in situ porosity is tenuous. However, the porosity of the clay is probably of the order of 68 to 70 per cent.

\section{REFERENCES}

American Society for Testing and Materials, 1964. Procedures for Testing Soils. 4th Edition, Philadelphia (American Society for Testing and Materials), 107.

Deer, W. A., Howie, R. A. and Zussman, J., 1963. Rock Forming Minerals. 4, New York (John Wiley and Sons).

Dixon, W. J. and Massey, F. J. Jr., 1957. Introduction to Statistical Analysis. New York (McGraw Hill Book Co., Inc.).
Gealy, E. L. and Gerard, R. D., 1970. In-Situ petrophysical measurements in the Caribbean, In Bader, R. D., et al., Initial Reports of the Deep Sea Drilling Project, Volume IV. Washington, D. C. (U. S. Government Printing Office), 267.

Graton, L. C. and Fraser, H. J., 1935. Systematic packing of spheres with particular relation to porosity and permeability. M. Geol. 43, 785.

Hamilton, E. L., 1956. J. Acoust. Soc. Am. 28, (1), 1.

Hamilton, E. L., 1969. Sound velocity, elasticity and related properties of marine sediments, North Pacific, Part 1: Sediment properties, environmental control and empirical relationships. U.S. Naval. Undersea Research and Development Center, Tech. Paper TP-143. (Also, J. Geophys. Res. in press.)

Hamilton, E. L. and Menard, H. W., 1956. Density and porosities of sea floor sediments off San Diego, California. Bull. Am. Assoc. Petrol. Geologists. 40, 754.

Igelman, K. R. and Hamilton, E. L., 1963. Bulk densities of mineral grains from Mohole samples (Guadalupe Site). J. Sediment. Petrol. 33, 474.

Krumbein, W. C. and Pettijohn, F. J., 1938. Manual of Sedimentary Petrography. (Appleton-CenturyCrofts, Inc.).

La Fonde, E. C., 1951. Processing oceanographic data. U.S. Navy Hydrographic Office, Publication No. 614. The Chemical Rubber Co., 1969, Handbook of Chemistry and Physics, 50th Edition, Cleveland, Ohio.

Robie, R. A., Bethke, P. M., Toulmin, M. S. and Edwards, J. L., 1966. X-Ray crystallographic data, densities and molar volumes of minerals. In Handbook of Physical Constants, Memoir 97. Clark, S. P. $\mathrm{Jr}$, (Ed.) (Geological Society of America).

Skinner, B. J., 1966. Thermal expansion, In Handbook of Physical Constants, Memoir 97. Clark, Sydney P. Jr., (Ed.) The Geological Society of America.

U. S. Navy Hydrographic Office, 1952. Tables for seawater density. Hydrographic Office Publication 615.

Winchell, Alexander N., 1947. Elements of Optical Mineralogy. New York (John Wiley and Sons, Inc.). 